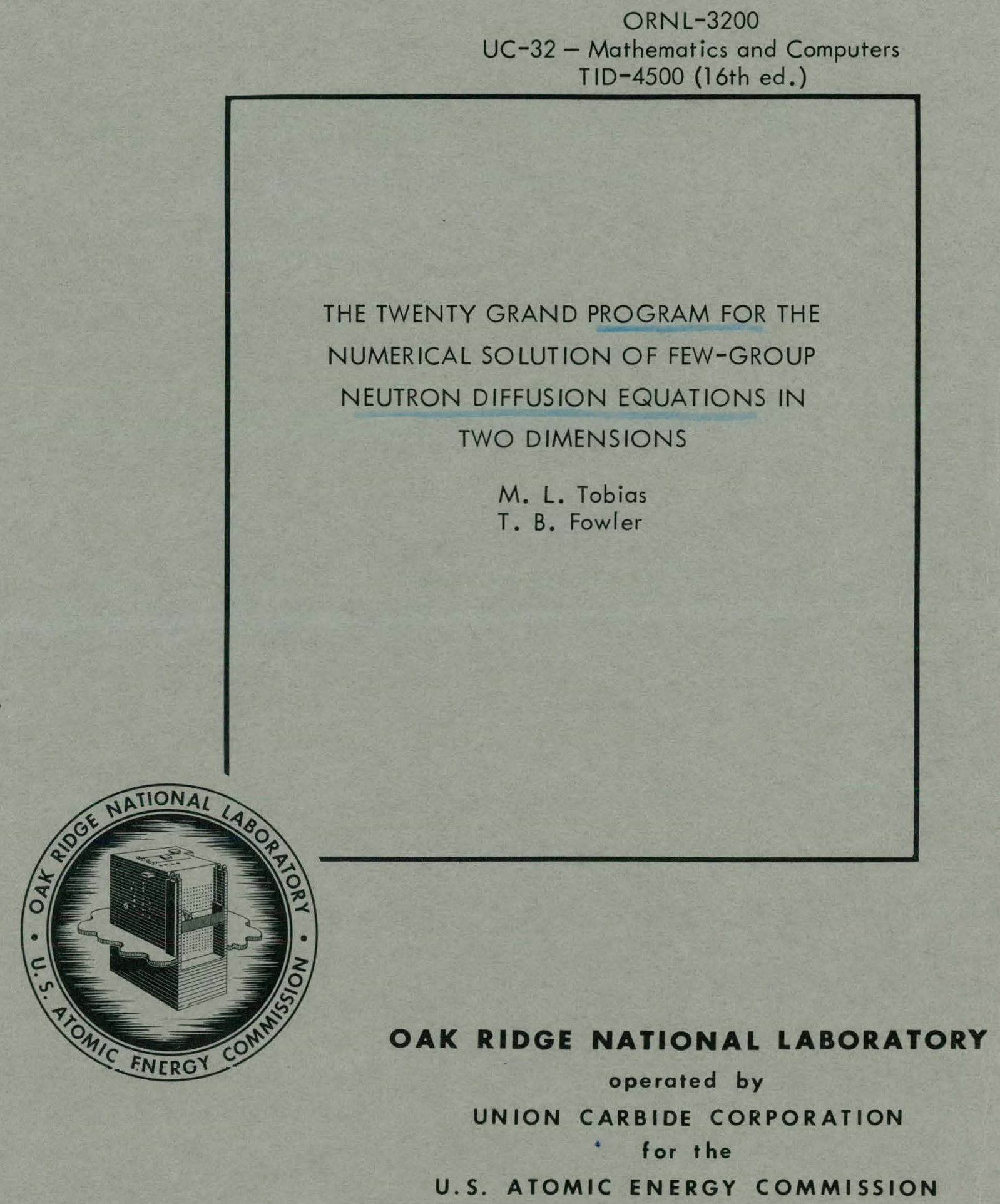




\section{DISCLAIMER}

This report was prepared as an account of work sponsored by an agency of the United States Government. Neither the United States Government nor any agency Thereof, nor any of their employees, makes any warranty, express or implied, or assumes any legal liability or responsibility for the accuracy, completeness, or usefulness of any information, apparatus, product, or process disclosed, or represents that its use would not infringe privately owned rights. Reference herein to any specific commercial product, process, or service by trade name, trademark, manufacturer, or otherwise does not necessarily constitute or imply its endorsement, recommendation, or favoring by the United States Government or any agency thereof. The views and opinions of authors expressed herein do not necessarily state or reflect those of the United States Government or any agency thereof. 


\section{DISCLAIMER}

Portions of this document may be illegible in electronic image products. Images are produced from the best available original document. 


\section{Printed in USA. Price $\$ 1.00$. Available from the \\ Office of Technical Services \\ Department of Commerce \\ Washington 25, D.C.}

\section{LEGAL NOTICE}

This report was prepared as an account of Government sponsored work. Neither the United States, nor the Commission, nor any person acting on behalf of the Commission:

A. Makes any warranty or representation, expressed or implied, with respect to the accuracy, completeness, or usefulness of the information contained in this report, or that the use of any information, apparatus, method, or process disclosed in this report may not infringe privately owned rights; or

B. Assumes any liabilities with respect to the use of, or for damages resulting from the use of any information, apparatus, method, or process disclosed in this report.

As used in the above, "person acting on behalf of the Commission" includes any employee or contractor of the Commission, or employee of such contractor, to the extent that such employee or contractor of the Commission, or employee of such contractor prepares, disseminates, or provides access to, ony information pursuant to his employment or contract with the Commission, or his employment with such contractor. 


$$
\text { ORNL- } 3200
$$
UC-32 - Mathematics and Computers TID-4500 (16th ed.)

Contract No. W-7405-eng-26

REACTOR DIVISION

THE TWENTY GRAND PROGRAM FOR THE NUMERICAL SOLUTION OF FEW-GROUP NEUTRON DIFFUSION EQUATIONS IN TTWO DIMENSIONS
M. L. Tobias
T. B. Fowler

DATE ISSUED

\section{FEB 219902}

OAK RIDGE NATIONAL LABORATORY

Oak Ridge, Tennessee

$$
\text { operated by }
$$

UINION CARBIDE CORPORATION

$$
\text { for the }
$$

U. S. ATOMIC ENERGY COMMISSION 


\section{THIS PAGE \\ WAS INTENTIONALLY \\ LEFT BLANK}




\section{CONTENTS}

Abstract

Introduction

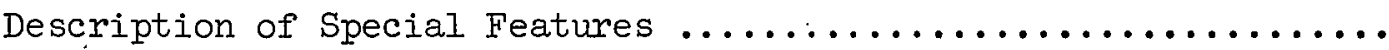

Scattering from any Group to any Group and Variable Buckling

Automatic Handling of Symmetry Coriditions

Normalization of Fluxes to an Arbitrary Power Level

Loydrithm1c-Derivative or Rod Boundary Conditions .......... 6

Integrals of Dot Products of Flux Gradients .............. 7

Input, Operating Instructions, Sample Problem ............. 7

Instructione for Writing TWENTY GRAND Input ............. 7

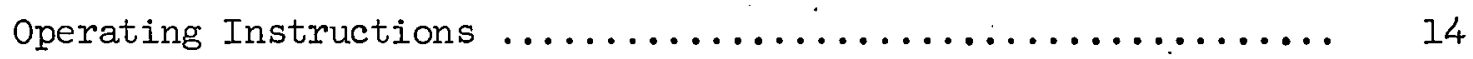

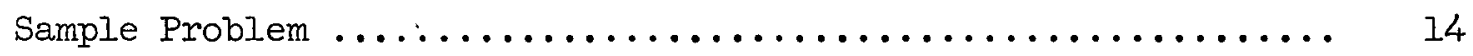




\title{
THE' TWENTY GRAND PROGRAM FOR THE NUMERICAL SOLUTION OF FEW-GROUP NEUTRON DIFFUSION EQUATIONS IN TWO DIMEINIONS
}

M. L. Tobias T. B. Fowler

\begin{abstract}
The TWENTY GRAND program for the IBM 7090 is capable of solving neutron diffusion problems in cylindrical or slab geometry for one to six groups. Up to 3000 mesh points may be used. Neutron transfer from any group to any other group is permitted. Teakage in the third dimension in $\mathrm{X}-\mathrm{Y}$ geometr.y may bc treated by a buckling which can vary with region and group. Three types or symmetry conditions may be handled. automatically. The zero flux, zero derivative, and logarithmic boundary conditions are available. Normalization of fluxes to an arbitrary input power is allowed. The fission source distribution and the adjoint fluxes and associated integrals may be computed at the user's option. The number of mesh sweeps permitted is stated as input. The average running time in seconds per point per iteration per group is approximately 0.0035 .
\end{abstract}

\section{Introduction}

TWENTY GRAND is a program based upon the Equipoise method; ${ }^{1}$ it solves the finite difference analogs of the neutron diffusion equations for one to six groups in $\mathrm{R}-\mathrm{Z}$ and $\mathrm{X}-\mathrm{Y}$ geometry. The program involves the following special features, which will be discussed in more detail in later sections:

1. Upscattering and downscattering are provided for neutron transfer from any group to any other group.

2. In $X-Y$ geometry, leakage in the third dimension may be taken into account by using a bucklting which varies with region and with group.

3. Three types of symmetry conditions may be handled automatically; "single-diagonal," "double-diagonal," and "mirror-diagonal" are the names given to these conditions.

1.M. L. Tobias and T. B. Fowler, EQUIPOISE - An IBM-704 Code for the Solution of Two-Group, Two-Dimensional, Neutron Diffusion Equations in Cylindrical Geometry, ORNL-2967, Oct. 17, 1960. 
4. Normalization of fluxes to an arbitrary power level is permitted.

5. The number of mesh sweeps is determined by the user.

In addition to these items, the following features which have been used in-earlier Equipoise-type programs are included:

1. Zero flux, zero-derivative, and logarithmic-derivative (rod) boundary conditions may be used.

2. Optional output includes the fission source distribution, the adjoint fluxes, and the following associated integrals for each region

$$
\int_{R} \phi_{i} \phi_{j}^{*} d V \quad i, j=1,2, \ldots \cdot G
$$

and

$$
\int_{\mathrm{R}} \nabla \phi_{i} \cdot \nabla \phi_{j}^{*} \mathrm{dV} \quad i=1,2, \ldots \mathrm{G},
$$

where $\phi$ and $\phi^{*}$ refer to the neutron flux and adjoint flux, respectively.

3. Leakages, absorptions, productions, and eigenvalues are listed.

4. As many as 3000 points may be treated.

\section{Description of Special Features}

Scattering from any Group to any Group and Variable Buckling

The special scattering and buckling features are enclosed in braces in the following equation for the neutron balance around an element of volume for the ith neutron group in the slab geometry shown in Fig. I:

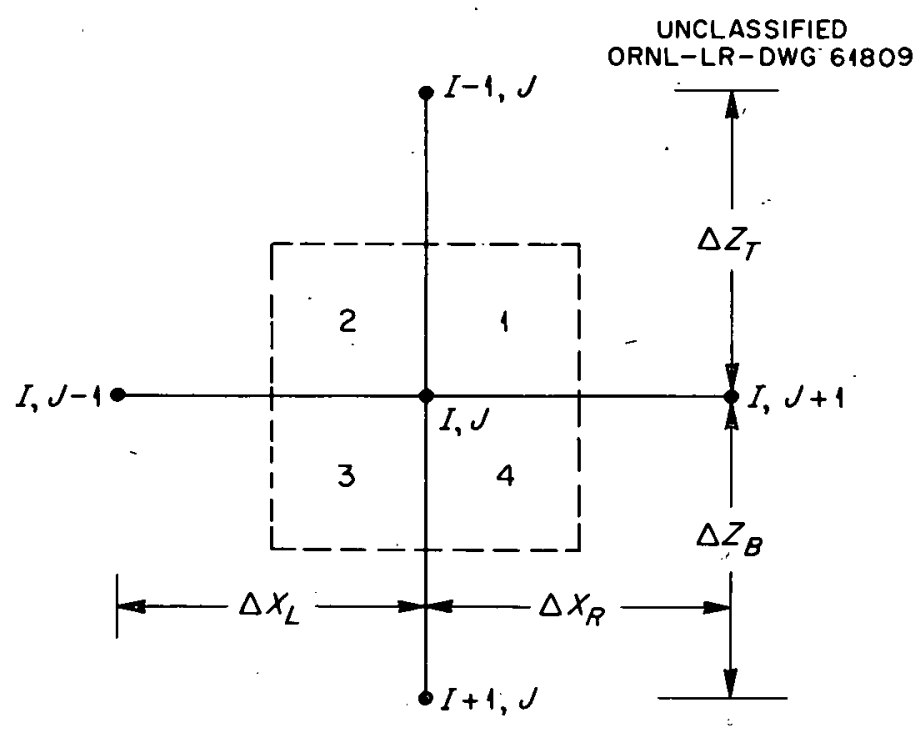

Fig. 1. Diagram of a Typical Mesh Point. 


$$
\begin{aligned}
& D_{1 i}\left[\phi_{i}(I-I, J)-\phi_{i}(I, J)\right] \frac{\Delta X_{R}}{2 \Delta Z_{T}}+\text { similar leakage terms } \\
& -\left\{D_{l i} B_{l i}^{2} \phi_{i}(I, J) \frac{\Delta Z_{1} \Delta X_{R}}{4}+\text { similar longitudinal leakage terms }\right\} \\
& -\Sigma_{\mathrm{Al} i} \phi_{i}(T, T) \frac{\Delta Z_{T} \Delta X_{R}}{4}+\text { similar absorption terma } \\
& -\Sigma_{\mathrm{Rli}} \phi_{i}(I, J) \frac{\Delta \nabla_{1, l} \wedge \mathrm{X}_{\hat{\mathrm{R}}}}{4}+\text { similar removal terms } \\
& +\left\{\sum_{j \neq i}^{G}\left[f_{I j \rightarrow i} \Sigma_{R I j} \phi_{j}(I, J) \frac{\Delta Z_{I} \Delta X_{R}}{4}+\text { similar "scattering-in" terms }\right]\right\} \\
& +\lambda x_{i}\left[\sum_{j=1}^{G} v \Sigma_{f l j} \phi_{j}(I, J) \frac{\Delta Z_{I} \Delta X_{R}}{4^{-}}+\text {similar source terms }\right]=0
\end{aligned}
$$

The iterative procedure is based upon solving this equation for $\phi_{i}(I, J)$, except that $\phi_{i}(I, J)$ is left in the source term. For cylindrical geometry, the surface and volume constants are suitably modified. The symbols used in Eq. 1 have the following meanings:

\section{Notation}

$\mathrm{B}_{\mathrm{li}}^{2}$

$D_{1 i}$

$$
f_{1 j \rightarrow i}
$$

i, $j$

$I, J$

$\Delta X_{R}$

$\Delta Z_{T}$

$\phi_{i}(I, J)$

$\lambda$
Square of group $i$ buckling of area $I$ at mesh point $(I, J), \mathrm{cm}^{-2}$ Group $i$ diffusion coefficient of area $I$ at mesh point $(I, J), \mathrm{cm}$ The fraction of neutrons removed from group $j$ that enter group i from area 1 at mesh point $(I, J)$

Subscripts denoting group number

Coordinates of mesh point $(I, J)$

Distance from mesh point $(I, J)$ to mesh point $(I, J+I), \mathrm{cm}$ Distance from mesh point $(I, J)$. to mesh point $(I-I, J)$, cm Group i flux at mesh point $(I, J)$

The eigenvalue of the problem; the value by which all $\nu \Sigma_{f}$ 's must be multiplied so that the difference equations will balance 


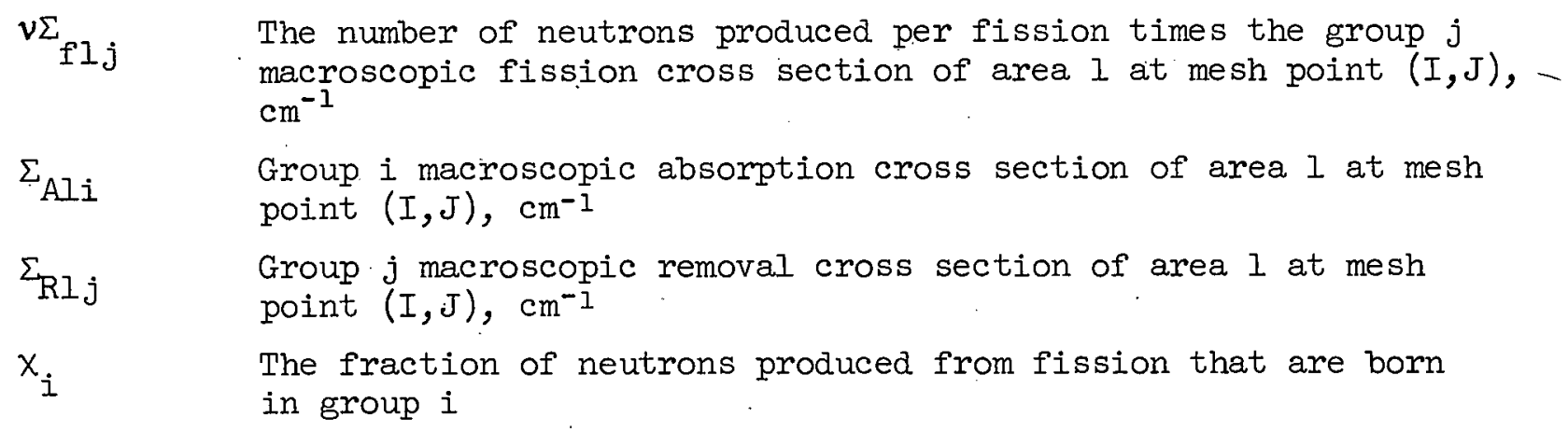

\section{Automatic Handling of Symmetry Conditions}

By suitable specification of the input it is possible to make the program compute in conformance with the following three types of symmetry conditions:

1. Single diagonal symmetry (square mesh only)

$$
\phi(I, J)=\phi(J, I)
$$

2. Double diagonal symmetry (square mesh only)

$$
\begin{gathered}
\phi(I, J)=\phi(J, I) \\
\phi(I, J)=\phi(J M A X-j+1, \text { IMAX-I+I) }
\end{gathered}
$$

3. Mirror diagonal symmetry

$$
\phi(I, J)=\phi(I M A X-I+I, J M A X-J+I),
$$

These conditions may be understood' by the sketches in Fig. 2.

Normalization of Fluxes to an Arbitrary Power Level

Unless specifically provided for in the input, all answers will be normalized to one source neutron; that is, the output is computed so that the sum of all sources $v \Sigma_{f i}(I, J) \phi_{i}(I, J) \Delta V$ is one neutron per second. By inserting an appropriate constant in the input, the answers may be 

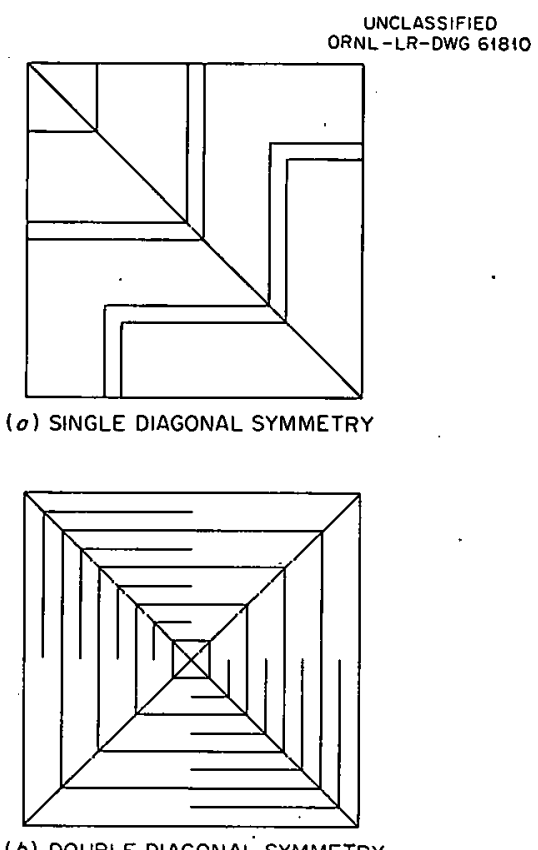

(b) DOUBLE DIAGONAL SYMMETRY

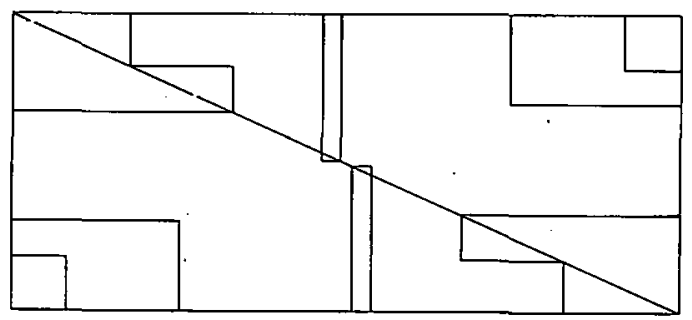

(c) MIRROR DIAGONAL SYMMETRY

Fig. 2. Sketches of Various Symmetry Conditions that Can Be Handled Automatically.

normalized to any desired power level. If the user assumes that there are $3.3 \times 10^{13}$ fissions per kilowatt per second and that $\nu=2.5$, the appropriate constant to be placed in the input for a power of 137. Mw would be:

$$
(137)(1000)(2.5)\left(3.3 \times 10^{13}\right)=11.3025 \times 10^{18}
$$

(Care must be used if only part of a reactor is being considered. If there were one symmetry boundary, the number above would be divided by 2 . Note also that this normalization to a given power corresponds to saying that the reactor is just critical with a fictitious fuel for which the 
number of neutrons per fission is $\lambda \nu$, where $\lambda$ is the eigenvalue computed by the program. There is, of course, no need to introduce $\lambda$ because it cancels out.)

\section{Logarithmic-Derivative or Rod Boundary Conditions}

The finite-difference equivalent of the logarithmic-derivative boundary condition

$$
\mathrm{D} \frac{\mathrm{d} \phi}{\mathrm{d} \overrightarrow{\mathrm{n}}}=-\mathrm{C} \phi
$$

may be used along the surfaces of "rod regions," which may be placed in the mesh in the same way as any other region (see Fig. 3 ).

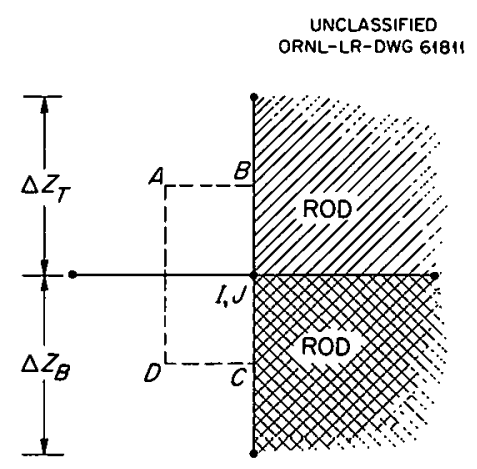

Fig. 3. Element of Volume Bordering on a Rod Region.

The rod region is treated as though it were introducing an absorption cross section rather than a leakage. The diffusion constant in the rod region is made zero for the group or groups considered as rod groups. Slowing down into a rod group is permitted, but there is no removal other than absorption. Leakage into the rod region from the element of volume $A B C D$ of Fig. 3 is handled by introducing terms such as the following into the neutron balance:

$$
-\left(\mathrm{C}_{1} \frac{\Delta \mathrm{Z}_{\mathrm{T}}}{2}+\mathrm{C}_{2} \frac{\Delta \mathrm{Z}_{\mathrm{B}}}{2}\right) \phi(I, J)
$$

where the C's may be regarded as the diffusion constants in the element 
$A B C D$ divided by extrapolation distances. Different.kinds of rods may adjoin one another along mesh lines.

Integrals of Dot Products of Flux Gradients

The integrals

$$
\int \nabla \phi_{i} \cdot \nabla \phi_{i}^{*} \mathrm{dV}
$$

are approximated by computing, over each region, the sum of terms such as the following:

$$
\begin{gathered}
\left\{\left[\frac{\phi_{i}(I-I, J)-\phi(I, J)}{\Delta Z_{T}}\right]\left[\frac{\phi_{i}^{*}(I-I, J)-\phi^{*}(I, J)}{\Delta Z_{T}}\right]+\right. \\
\left.+\left[\frac{\phi_{i}(I, J+I)-\phi_{i}(I, J)}{\Delta X_{R}}\right]\left[\frac{\phi_{i}^{*}(I, J+I)-\phi_{i}(I, J)}{\Delta X_{R}}\right]\right\} \frac{\Delta Z_{T} \Delta x_{R}}{4} .
\end{gathered}
$$

This computation is done at the user's option.

\section{Input, Operating Instructions, Sample Problem}

Instructions for Writing TWENTY GRAND Input

Figure 4 shows a TWENTY GRAND input form filled in for the sample problem. Given below are the instructions for writing the input. Number formats are in FORTRAN nomenclature and are given in parenthesis immediately following each input number symbol.

Title Card. Column 1 of the title card is left blank. Columns 2 through 72 may contain any desired information and are printed at the top of each page of output.

Control Card 1. Columns 1 through 3, ITMAX(I3) $\leqslant$ 999: Total number of iterations a problem is to be run. If a problem has not converged before the number of iterations has reached ITMAX, it is terminated automatically and all output is written. Usually problems reach convergence in fewer than 300 iterations. 


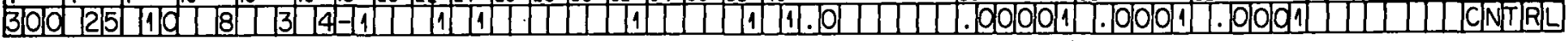

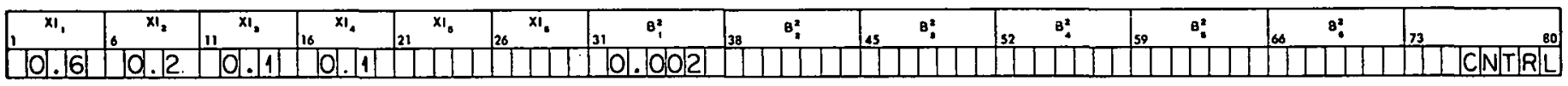

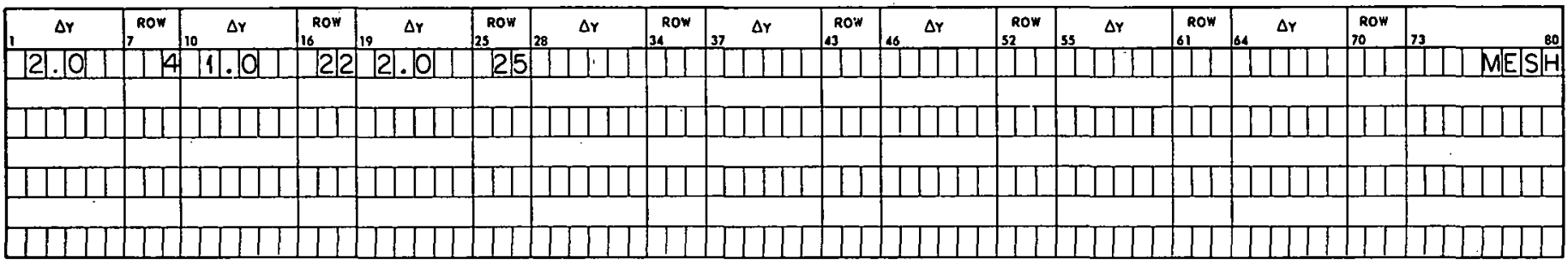

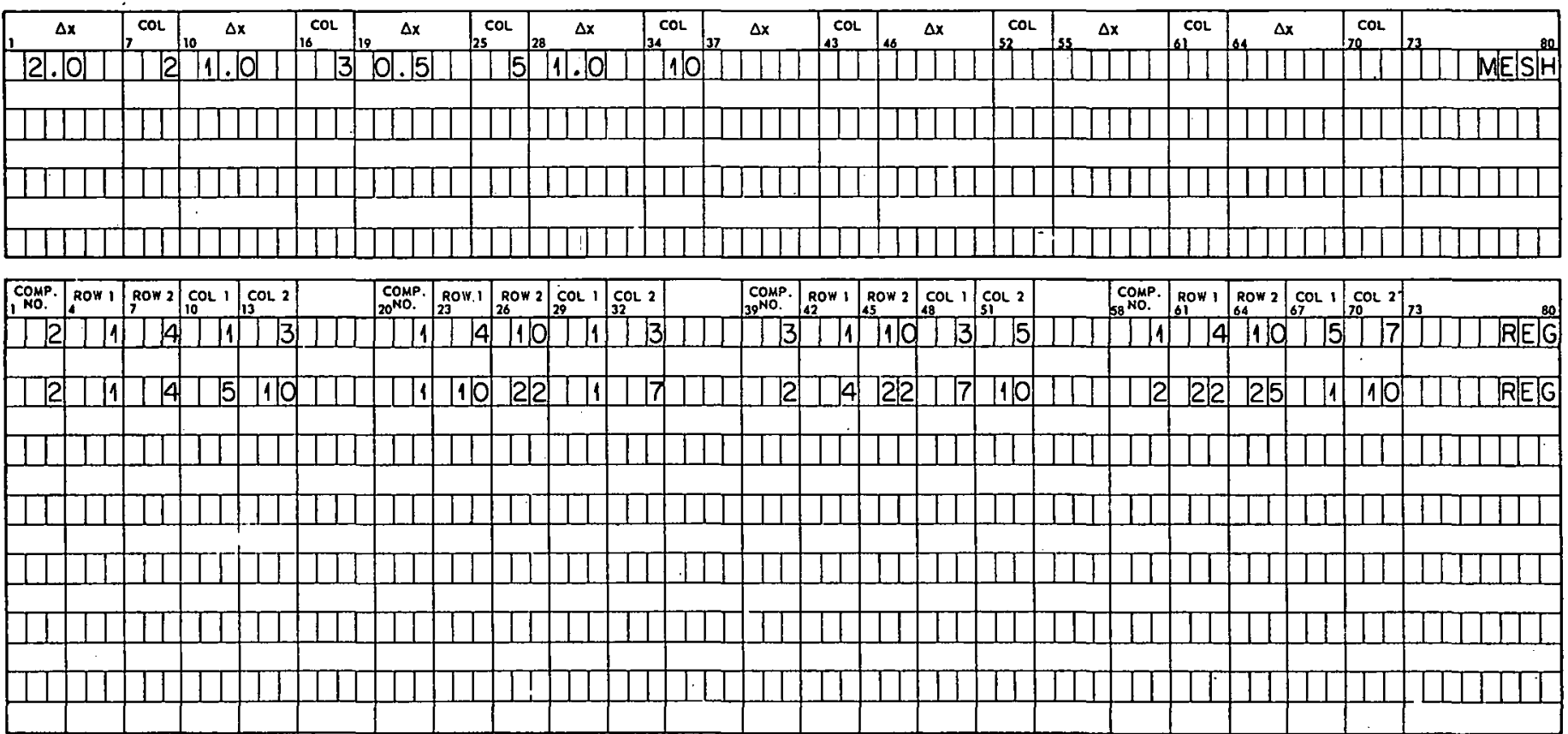

Fig. 4. Input for Sample Problem. 


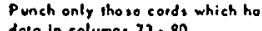

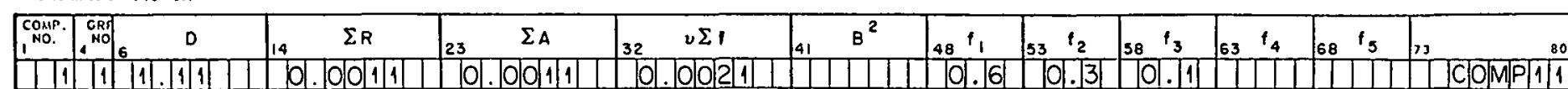

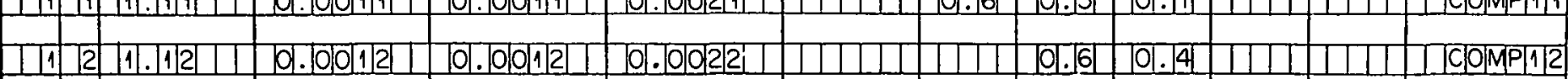

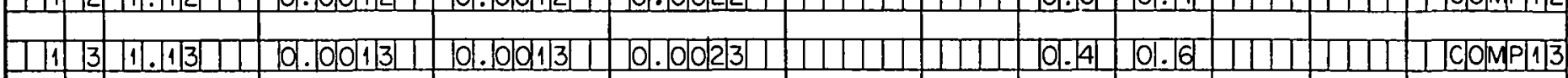

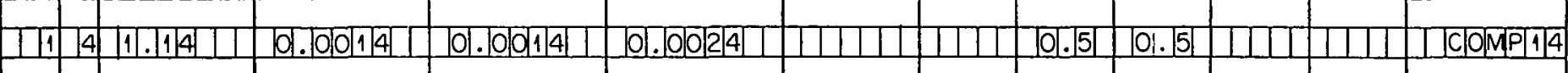

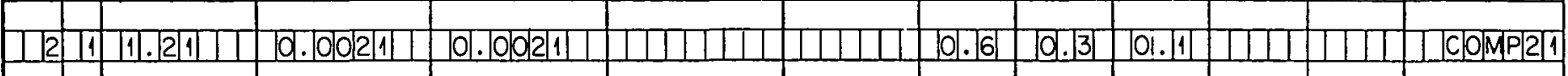

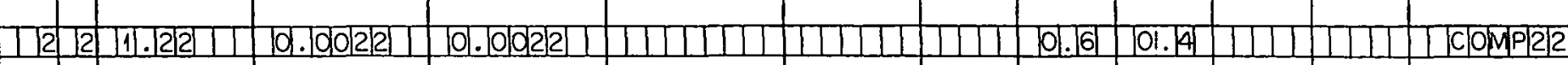

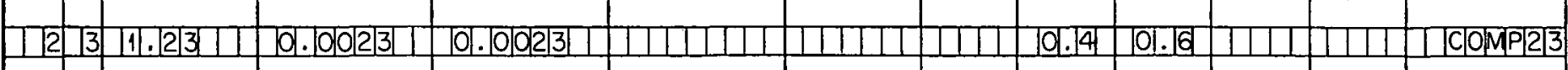

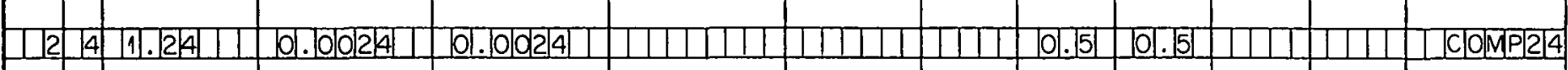

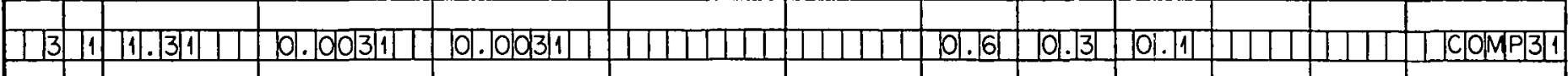

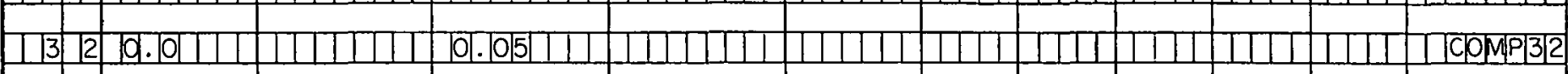

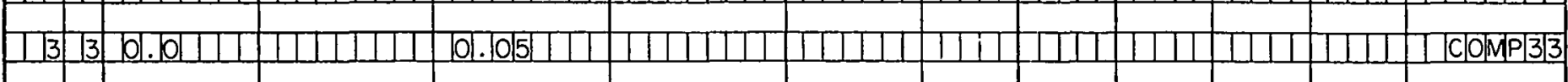

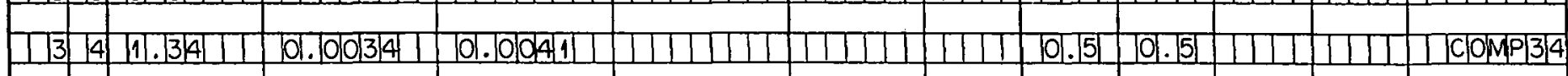

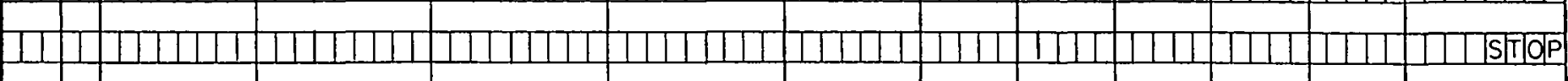

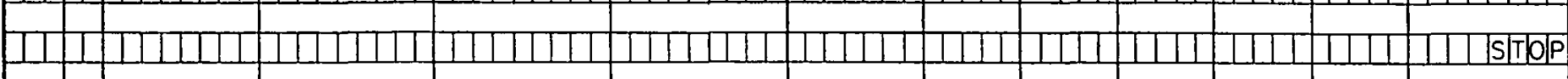

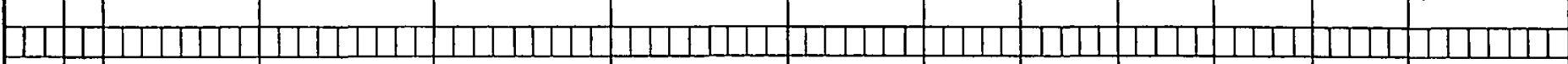

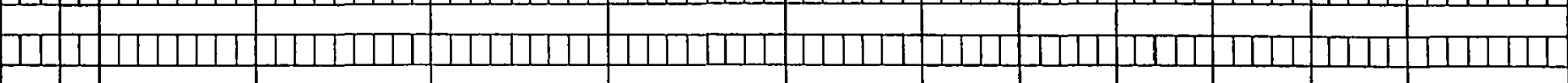

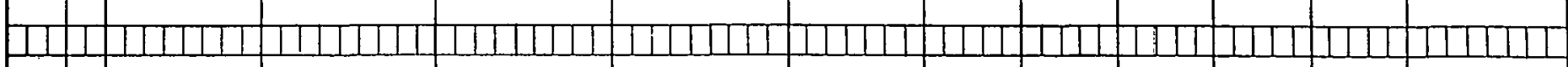
एस

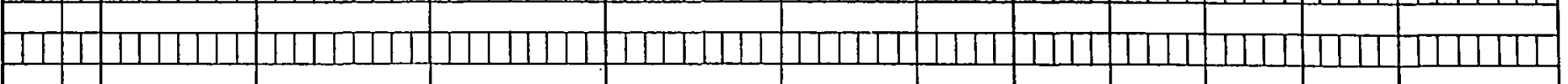

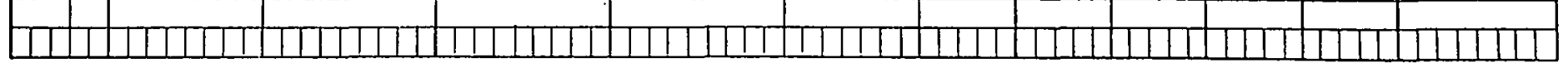


Columns 4 through 6, IMAX(13) $\leqslant 100$ : Total number of rows in the mesh. The rows are numbered from top to bottom beginning with 1 and ending with IMAX.

Columns 7 through 9, JMAX(I3) $\leqslant 100$ : Total number of columns in the mesh. The columns are numbered from left to right beginning with $I$ and ending with JMAX. Note that IMAX $\times$ JMAX $\leqslant 3000$.

Columns 10 through 12, NR(I3): Total number of rectangular regions that are specified on the region-specification cards (see below). Normally this number must be less than or equal to 100; however, for the adjoint calculation $\mathrm{NR} \leqslant 70$.

Columns 13 through 15, NC(I3) $\leqslant 50$ : Total number of compositions that are specified on the composition-specification cards (see below).

Columns 16 through 17, NG(I2) $\leqslant 6$ : Total number of groups.

Columns 18 through 19, GI(I2): Geometry indicator. For cylindrical geometry write +1 ; for slab geometry write -1 .

Columns 20 through 2I, BI(I2): Buckling indicator for slab geometry. A -1 specifies buckling by region (or composition). The bucklings are given on the composition-specification cards. A +l specifies buckling by group, in which case the bucklings are given on Control Card 2. A 0 or blank specifies a constant buckling, the value of which is written in columns 31 through 37 of control card 2 .

Columns 22 through 23, SI(I2): Source indicator. If this number is +1 , the source

$$
\sum_{i=1}^{G}\left(\nu \Sigma_{f} \phi\right)_{i}
$$

for each of the four quadrants surrounding each mesh point is included in the output. If SI is 0 or blank, the source calculation is skipped.

Columns 24 through 25, AI(I2): Adjoint indicator. If this number is +1 , the adjoint calculation is done automatically following the ordinary flux calculation. If AI is $O$ or blank the adjoint calculation is skipped.

Columns 26 through 27, FI(I2): Previous flux indicator. If FI is +1 , the final flux from the previous problem is used as the initial flux 
guess for the present problem. The present problem must have the same mesh and boundary conditions as the previous problem. If FI is 0 or blank, the code supplies an initial flux guess of 100.

Columns 28 through 29, CI(I2): Convergence indicator. If CI is -1 , the calculation stops when

$$
\left|\frac{\lambda^{t}}{\lambda^{t+1 n}}-1\right|<\epsilon(\lambda)
$$

where $\lambda$ is the eigenvalue of the problem and $t$ is the iteration number. If $\mathrm{CI}$ is +1 , the calculation stops when the above condition is met and the following flux convergence condition is satisfied:

$$
\left.\left|\frac{\phi_{i}^{t}(J, J)}{\phi_{i}^{t+1}(I, J)}-I\right|\right|_{\max }<\epsilon(\phi)
$$

If CI is $O$ or blank, the calculation stops when both the above conditions are met, as well as the residue condition,

$$
\left[\sum_{i} \sum_{I, J} R_{i}^{2}(I, J)\right]^{1 / 2}<\epsilon(R),
$$

where $R$ is the residue per one source neutron calculated from equations such as (1).

Columns 30 through 31, DI(I2): Diagonal symmetry indicator. If this number is +1 , the code assumes that the problem has one diagonal symmetry axis passing through mesh point $(1,1)$. A +2 designates two diagonal symmetry axes. A - I for DI specifies mirror image symmetry, with the symmetry axis passing through mesh point $(1,1)$. If DI is 0 or blank, then no diagonal symmetry axis exists for the problem.

Columns 32 through 33, LB(I2): Left boundary indicator. If LB is 0 or blank, the left boundary of the reactor is a zero flux boundary. If LB is +1 , a symmetry boundary is assumed to exist midway between columns 1 and 2 . 
Columns 34 through 35, TB(I2): Top boundary indicator. If TB is 0 or blank, the top boundary of the reactor is a zero flux boundary. If this number is +1 , a symmetry boundary is assumed to exist midway between rows 1 and 2 .

Columns 36 through 37, $\mathrm{RB}(\mathrm{I2})$ : Right boundary indicator. A 0 or blank for this number specifies a zero flux boundary at the right of the reactor. If this number is +1 , a symmetry boundary exists midway between columns JMAX-1 and JMAX.

Columns 38 through 39, BB(I2): Bottom boundary indicator. Write 0 or leave blank to specify a zero flux boundary. Write tl to specify a symmetry boundary midway between rows IMAX-1 and IMAX.

Columns 40 through 49, NORM FACTOR (ElO.6): All the fluxes are multiplied by this number and divided by the total source for output.

Columns 50 through 55, $\epsilon(\lambda)$ (E6.3): Convergence criterion for $\lambda$ convergence condition given by Eq. (6). A value of $10^{-5}$ is reasonable for this number.

Columns 56 through 6l, $\epsilon(\phi)$ (E6.3): Convergence criterion for flux convergence condition given by Eq. (7). A value of $10^{-4}$ for this number will usually assure reasonable convergence.

Columns 62 through 67, $\epsilon(R)$ (E6.3): Convergence criterion for residue convergence condition given by Eq. (8). This number should be of the order of $10^{-5}$ for reasonable convergence.

Columns 68 through 72, B(F5.4): Extrapolated Liebmann coefficient. If this number is zero or blank, $\beta$ is computed by the code. If this number is a positive number between 1 and 2 , the value given is used.

Control Card 2. Columns 1 through 5, 6 through 10, 11 through 15, 16 through 20, 21 through 25, 26 through 30; XI $(F 5.4)$ : The fraction of neutrons produced from fission that are born in group $i$. Note that

$$
\sum_{i=1}^{K} X I_{i}=1.0 .
$$

Columns 31 through 37, 38 through 44, 45 through 51, 52 through 58, 59 through 65, 66 through 72; $\mathrm{B}_{i}^{2}(\mathrm{E7} .4)$ : Constant buckling value or 
group-dependent buckling values for slab geometry. If the constant buckling option was used (see above), the value is written in columns 31 through 37. The group-dependent buckling values are written in the appropriate columns.

Mesh Specification Cards. In columns 1 through 6, 7 through 9; 10 through 15, 16 through 18; etc., specify $\triangle \mathrm{Y}(\mathrm{B} 6.3)$ and the row number (I3) up to which this $\Delta Y$ applies, going from top to bottom of the mesh. Use as many cards as are needed, with each card completely filled through column 72, except possibly the last card. The last number on these cards is equal to IMAX. Repeat as above, supplying values of $\triangle X(E 6.3)$ and the column number (I3) up to which this $\Delta \mathrm{X}$ applies, going from left to right of the mesh.

Region Specification Cards. The regions of the reactor are specified as rectangles. For each region specify the composition number (13:), top. row number (I3), bottom row number (I3), left column number (I3), andright column number (I3). The compositions are numbered beginning with I (see; below); however, more than one region may have the same.composition number.

Composition Specification Cards. For each different composition number specified above, $K$ composition specification cards are written, where $\mathrm{K}$ is the total number of groups. For each card the following numbers are specified.

Columns I through 3: Composition number (I3).

Columns 4 through 5: Group number (I2).

Columns 6 through 13, D(E8.5): Diffusion coefficient. Note that if $\mathrm{D}=0$, then $\Sigma_{\mathrm{R}}=\nu \Sigma_{\mathrm{f}}=0$ and $\Sigma_{\mathrm{A}}=\mathrm{C}$. This specifies a rod group.

Columns 14 through 22, $\Sigma_{\mathrm{R}}(\mathrm{E} 9.6)$ : Macroscopic removal cross section. Columns 23 through $31, \Sigma_{A}(E 9.6)$ : Macroscopic absorption cross section.

Columns 32 through 40, $v \Sigma_{f}(E 9.6): v$ times macroscopic fission cross section.

Columns 41 through 47, $\mathrm{B}^{2}(\mathrm{E7} .4)$ : Composition-dependent buckling. Columns 48 through 52, 53 through 57, 58 through 62, 63 through 67, 68 through $72 ; f_{l}^{i}(F 5.4)$ : The fraction of neutrons removed from group $i$ (the group number specified in columns 4 through 5) that enter group $l$ 
(i $\neq l$ ) for this composition. The value of $l$ goes from the smallest group number to the largest group number. Note that the number of $f^{\prime} s$ specified is one less than the total number of groups, since no $f$ is given for the group number specified in columns 4 through 5. Also, with reference to Fig. 4, the f's are always specified by beginning in column 48. For example, in specifying group one of a three-group problem, $f_{1}$ and $f_{2}$ (the $f^{\prime} s$ are labeled $f_{1}, f_{2}, f_{3}, f_{4}, f_{5}$ in Fig. 4) would designate the fraction of removals from group one to groups two and three, respectively. For group two, $f_{1}$ and $f_{2}$ would be the fraction of removals from group two to groups one and three. In specifying group three, $f_{1}$ and $f_{2}$ would be the fraction of removals from group three to groups one and two.

The sum of the f's on each card must be 1.0 unless $\Sigma_{R}=0$.

\section{Operating Instructions}

TWENTY GRAND was programmed to run under control of the IBM-7090 FORTRAN monitor system. A "job" consists of the program deck with the associated monitor control cards followed by the input data for as many cases to be run as desired. Two blank cards following the data deck will stop the calculation. The logical tape numbers used in the code are the following.

1. Tape 9: output

2. Tape 10: input

3. Tape 8: scratch tape needed only for source calculation or adjoint calculation.

One tape is used by the monitor for storage of the program chain links. This tape must be actual tape number BI.

\section{Sample Problem}

Figure 5 shows the diagram of the sample problem. It was run as a four-group problem in slab geometry. Figure 6 gives the output.

Note that mesh increments, not total distances, are supplied as input. With reference to Fig. 5, $\Delta \mathrm{X}$ between columns 5 and 10 is $1 \mathrm{~cm}$, whereas the distance from column 5 to column 10 is $5 \mathrm{~cm}$. 


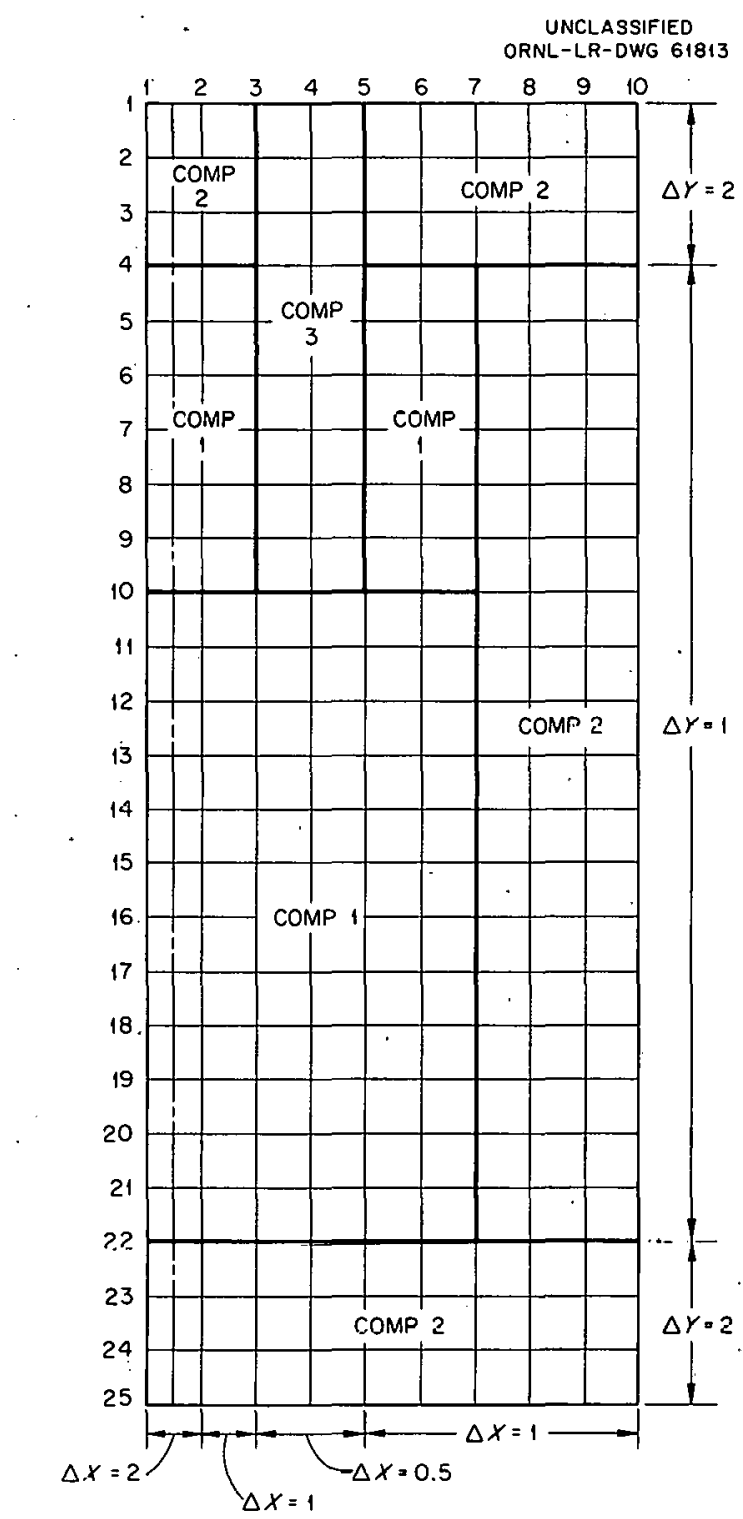

Fig. 5. Diagram of Sample Problem. 
CODE TWENTY GRAND - SAMPLE PROBLEM

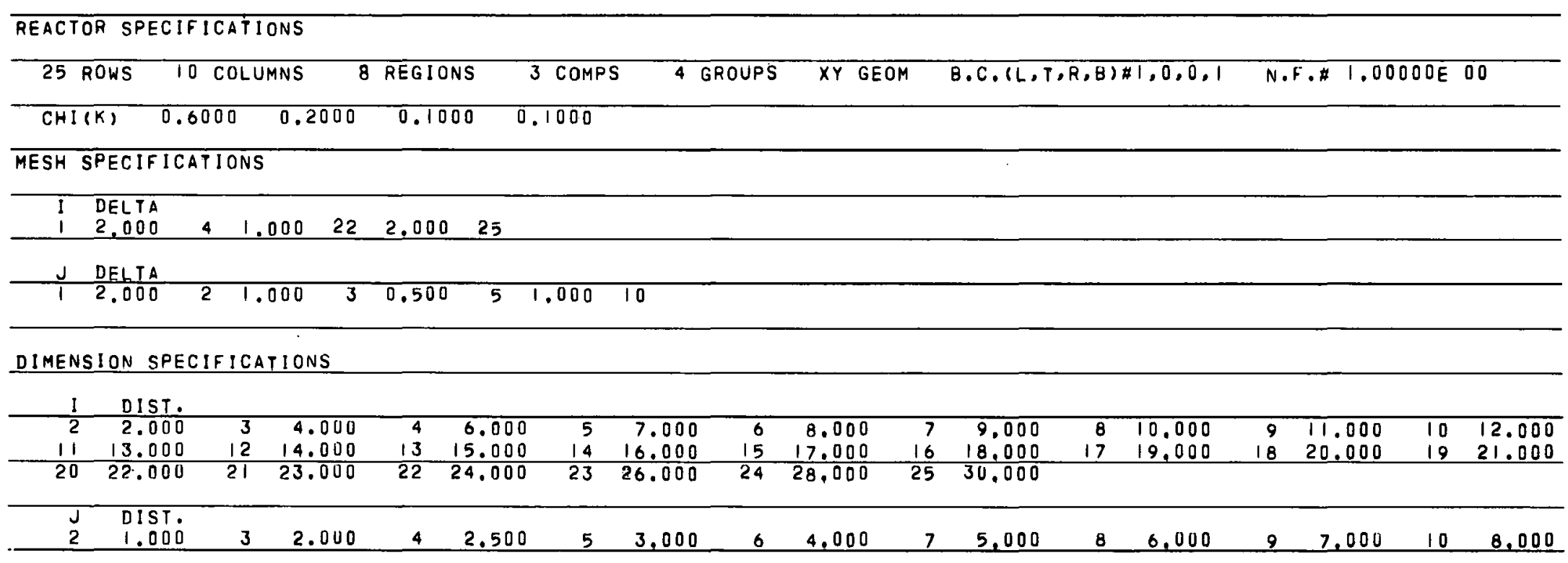

Fig. 6. Output for Sample Problem. 
CODE TWENTY GRAND - SAMPLE PROBLEM

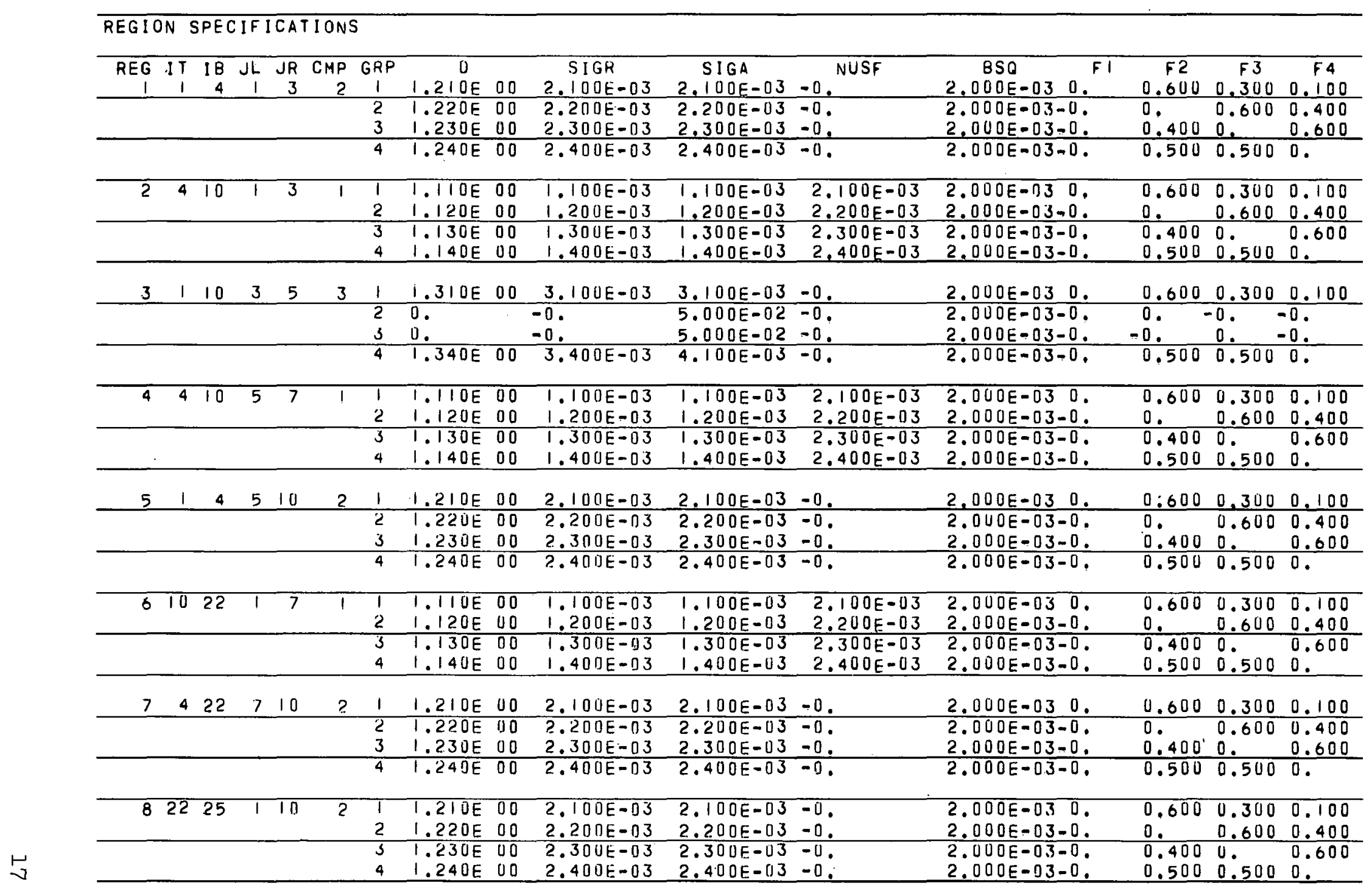

Fig. 6 (continued) 
CODE TWENTY GRAND - SAMPLE PROBI_EM

\begin{tabular}{cccccc}
\hline FLUX CALCULATION BEGINS & BETAE I.7364E 00 \\
\hline IT NO & FLUX CONVR & NU-CRIT CONVR & TOT RESIDUE & MAX RESIDUE & NU-CRITICAL \\
10 & $1.1404 E-01$ & $1.0000 E 00$ & $3.1558 E-02$ & $4.9995 E-03$ & $4.09722 E 01$ \\
\hline 20 & $2.3571 E-01$ & $2.2999 E-01$ & $3.1345 E-02$ & $4.0834 E-03$ & $3.33112 E 01$ \\
30 & $1.2156 E-02$ & $1.4841 E-03$ & $8.9851 E-03$ & $1.5777 E-03$ & $3.33607 E 01$ \\
\hline 40 & $4.8044 E-03$ & $4.1302 E-03$ & $1.9210 E-03$ & $4.4730 E-04$ & $3.34990 E 01$ \\
50 & $6.1990 E-04$ & $7.9259 E-04$ & $2.3835 E-04$ & $5.6123 E-05$ & $3.35256 E 01$ \\
\hline 60 & $8.0511 E-05$ & $1.1065 E-04$ & $2.9666 E-05$ & $7.1194 E-06$ & $3.35293 E$ \\
70 & $8.7619 E-06$ & $1.4238 E-05$ & $3.2847 E-06$ & $7.4762 E-07$ & $3.35298 E 01$ \\
\hline 80 & $7.3016 E-07$ & $1.6242 E-06$ & $7.3943 E-07$ & $1.1271 E-07$ & $3.35298 E 01$
\end{tabular}

Fig. 6 (continued) 
CODE TWENTY GRANI] - SAMFLE PROBLEM

NO.1T.\#80 NU-CRIT\#3.35298E OI N.F.C(TOI PROD)E E.2554IE-03

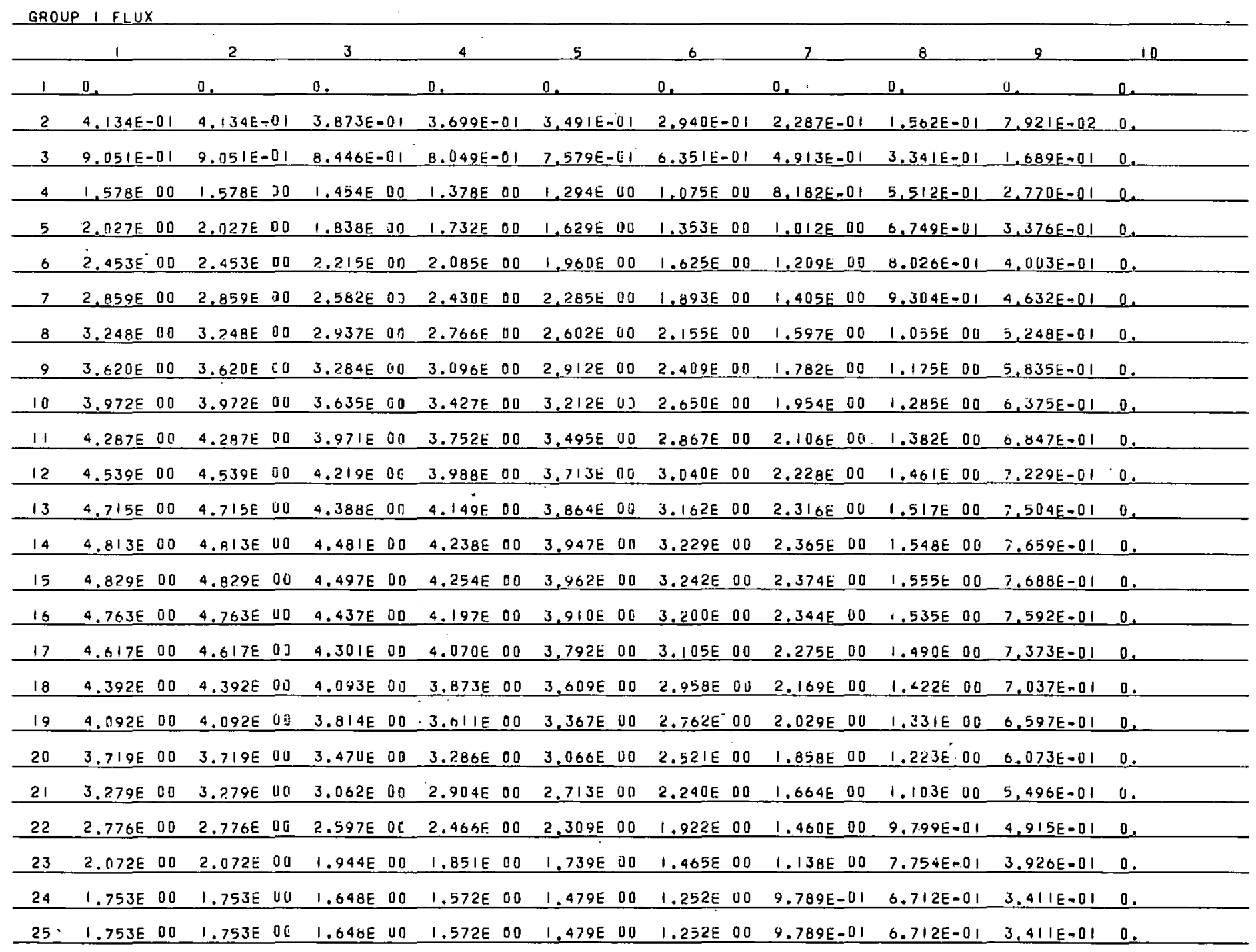

Fig. 6 (continued) 
CODE TWENTY GRAND - SAMPLE PROBLEM

\begin{tabular}{|c|c|c|c|c|c|c|c|c|c|c|}
\hline & 1 & 2 & 3 & 4 & 5 & 6 & 7 & 8 & 9 & $\underline{0}$ \\
\hline 1 & 0 & 0. & 0. & 0. & 0. & 0. & 0. & 0. & 0. & \\
\hline 2 & $2.589 E-01$ & $.589 E=01$ & $51|E-0|$ & 0 & $3,160 E-02$ & $3.100 E-02$ & $2.677 E-02$ & $1.958 E-02$ & $1.032 E-02$ & \\
\hline 3 & $5.421 E-01$ & $5.421 E-01$ & $.257 E-01$ & 0. & $7,740 E-02$ & $7.570 E-02$ & $0.489 E-02$ & $4.710 E-02$ & $2,469 E-02$ & \\
\hline 4 & $8.759 E-01$ & $8.759 E-01$ & $8.484 E-01$ & 0. & $1.602 E-01$ & $1.553 E-01$ & $1.300 E-01$ & $9.244 E-02$ & $4.789 E-02$ & \\
\hline 5 & $1.070 E \quad 00$ & $1.070 E \quad 00$ & $1.035 \mathrm{E} \quad 00$ & 0. & $2,297 E-01$ & $2.212 E-01$ & $1.799 E-01$ & $1.254 E-01$ & $0.437 E-02$ & \\
\hline 6 & $1.239 E \quad 00$ & $1.239 \mathrm{E} \quad 00$ & $1.197 E 00$ & 0. & $3.073 E-01$ & $2.951 E-01$ & $2.381 E-01$ & $1.647 E-01$ & $0.413 E-02$ & \\
\hline 7 & $1.376 E \quad 00$ & $1.376 E 00$ & $1.329 \mathrm{E} \quad 00$ & 0. & $4.012 E-01$ & $3.834 E-01$ & $3.071 E-01$ & $2.112 E-01$ & $1.074 E-01$ & \\
\hline 8 & $1.478 E \quad 00$ & $1.478 E \quad 00$ & $1.424 E \cup 0$ & 0. & $5.240 E-01$ & $4.942 E-01$ & $3,90 \mid E-01$ & $2.656 E-01$ & $1.341 E-01$ & \\
\hline 9 & $1.541 E 00$ & $1.541 E \quad 00$ & $1.469 E$ UD & 0. & $7.039 E-01$ & $0.375 E-01$ & $4.884 E-01$ & $3.270 E-01$ & $1.636 E-01$ & \\
\hline 10 & $1.569 E 00$ & $1.569 \mathrm{E} \quad 00$ & $1.428 E 00$ & $1.244 E 00$ & $1.022 E \quad 00$ & $8.154 E-01$ & $5.954 \mathrm{E}-01$ & $3.905 E-01$ & $1.936 E-01$ & \\
\hline 11 & $1.603 E \quad 00$ & $1.603 E \quad 00$ & $1.454 \mathrm{E} \quad 00$ & $1.337 E 00$ & $1.205 E \quad 00$ & $9.518 \mathrm{E}-01$ & $6.804 E-01$ & $4.467 E-01$ & $2,204 E-01$ & \\
\hline 12 & $1.644 E \quad 00$ & $1.644 E \quad 00$ & $1.508 E \cup 0$ & $1.410 E 00$ & $1.297 E 00$ & $1.040 E 00$ & $7.529 \mathrm{E}-01$ & $4.900 E-01$ & $2.416 E-01$ & \\
\hline 13 & $1.077 E 00$ & $.677 E \quad 00$ & $.550 E \quad 00$ & $1.459 E \quad 00$ & $1.351 E 00$ & $1.095 E \quad 00$ & $7.964 E-01$ & $5.196 E-01$ & $2.565 E-01$ & 0. \\
\hline 14 & $1.695 E \quad 00$ & $1.695 E 00$ & $1.572 \mathrm{E} \quad 00$ & $1.484 E \quad 00$ & $1.379 E \quad 00$ & $1.123 E \quad 00$ & $8.202 E-01$ & $5.365 E-01$ & $2.65 \mid E-01$ & \\
\hline 15 & $1.690 E 00$ & $1.690 E 00$ & $1.572 \mathrm{E} \quad 00$ & $1.485 E \quad 00$ & $1.382 E \quad 00$ & $1.129 \mathrm{E} \quad 00$ & $8.269 \mathrm{E}-01$ & $5.418 E-01$ & $2.68|E-0|$ & \\
\hline 16 & $1.662 \mathrm{E} \quad 00$ & $1.662 E 00$ & $1.547 E 00$ & $1.463 E 00$ & $1.362 E$ VO & $1.115 \mathrm{E} \quad 00$ & $8.181 E-01$ & $5.368 E-01$ & $2.658 E=01$ & \\
\hline 17 & $1.609 E 00$ & $1.609 E \quad 00$ & $1.499 \mathrm{E} \quad 00$ & $1.418 E 00$ & $1.321 E 00$ & $1.083 E \quad 00$ & $2.953 E-01$ & $5.223 E-01$ & $2,58 \mathrm{BE}-01$ & \\
\hline 18 & $1.530 E 00$ & $1.530 E \quad 00$ & $1.426 \mathrm{E} \quad 00$ & $1.350 E \quad 00$ & $1.258 E \quad 00$ & $1.032 E \quad 00$ & $7.594 \mathrm{E}-01$ & $4.993 E-01$ & $2.476 E-01$ & \\
\hline 19 & $1.428 \mathrm{E} \quad 00$ & $1.428 E 00$ & $1.331 \mathrm{E} 00$ & $1.261 E 00$ & $1.176 \mathrm{E} \quad 00$ & $9.600 E-01$ & $7.119 E-01$ & $4.689 E-01$ & $2.328 E-01$ & \\
\hline 20 & $1.302 \mathrm{E} \quad 00$ & $1.302 E 00$ & $1.215 E$ OD & $1.151 E 00$ & $1.074 E \quad 00$ & $8.849 E-01$ & $6.544 E-01$ & $4.324 E-01$ & $2.15 \mid E-01$ & \\
\hline 21 & $1.154 E 00$ & $1.154 E \quad 00$ & $1.078 E \quad 00$ & $1.023 E 00$ & $9.558 \mathrm{E}-01$ & $7.907 E-01$ & $5.894 E-01$ & $3.918 E-01$ & $1.957 E-01$ & \\
\hline 22 & $9.863 E-01$ & $9.863 E-01$ & $9.230 E-01$ & $8.767 E-01$ & $8.21|E-0|$ & $6.844 E-01$ & $5.2 \mid 1 E-01$ & $3.506 E=01$ & $1.761 E-01$ & \\
\hline 23 & $7.505 E-01$ & $7.505 E-01$ & $7.044 E-01$ & $6.708 E-01$ & $6.305 E-01$ & $5.314 E-01$ & $4.130 E-01$ & $2.818 E-01$ & $1.428 E-01$ & \\
\hline 24 & $0.431 E-01$ & $0.431 E-01$ & $6.047 E-01$ & $5.765 E-01$ & $5.428 E-01$ & $4.597 E-01$ & $3.595 E-01$ & $2.466 E-01$ & $1.253 E-01$ & 1. \\
\hline 25 & $0.431 E-01$ & $6.431 E-01$ & $6.047 E-C 1$ & $5.765 E-01$ & $5.428 E-01$ & $4.597 E-01$ & $3.595 E=01$ & $2.460 E-01$ & $1.253 E-01$ & \\
\hline
\end{tabular}

Fig. 6 (continued) 
CODE TUENTY GRAND - SAMPLE PROBLEM

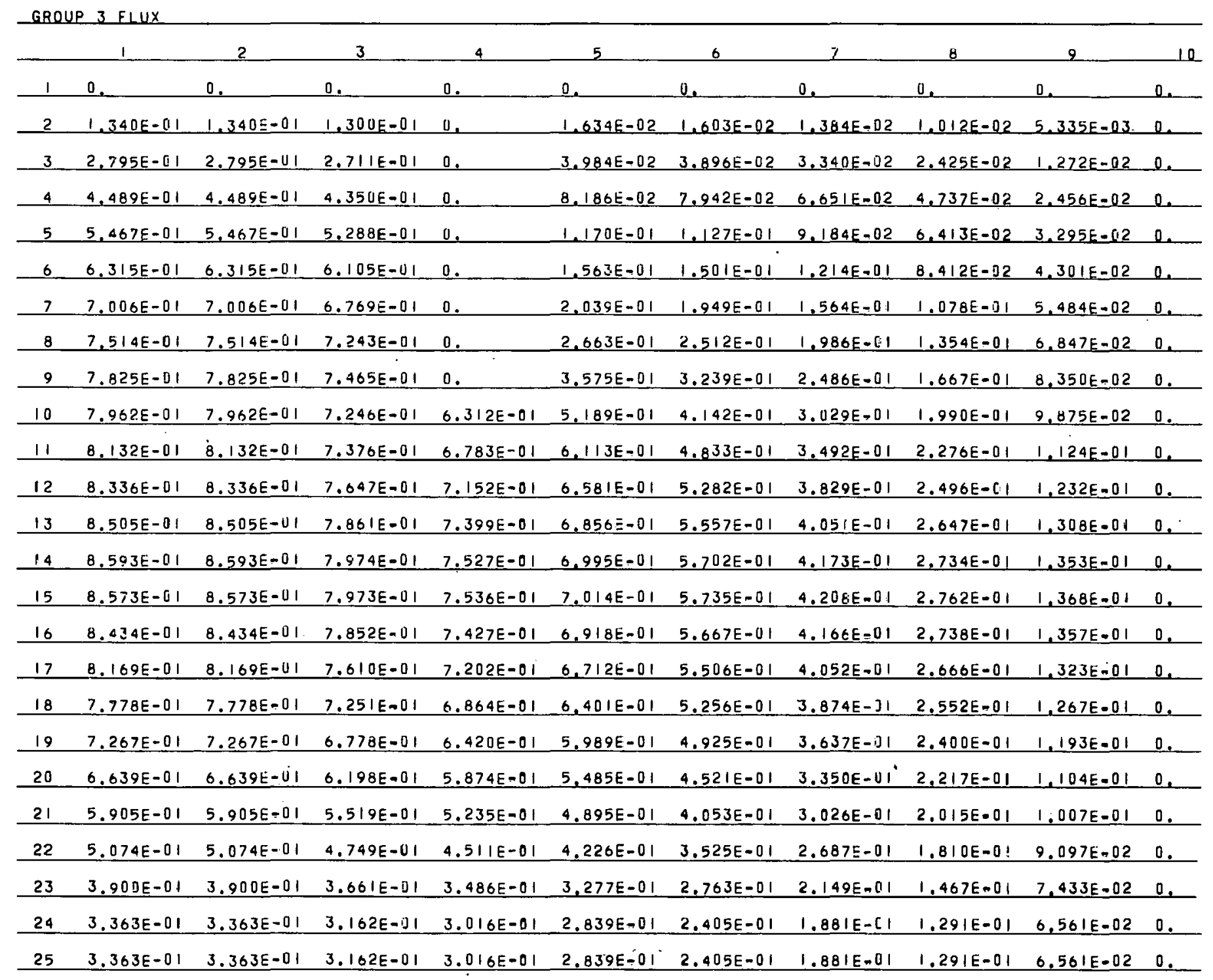


CODE IWENTY GRAND - SAMPLE PROBLEM

\begin{tabular}{|c|c|c|c|c|c|c|c|c|c|}
\hline & 1 & 2 & 3 & 4 & 2 & 6 & 1 & 9 & \\
\hline 1 & 0. & 0. & 0 & 0 & 0. & 0. & 0 & 0. & \\
\hline$\underline{2}$ & $7.159 \mathrm{E}-02$ & $.159 E-02$ & $E-Q 2$ & $377 E$ & & 5.05 & $\underline{02}$ & 2,6 & 0. \\
\hline 3 & $1.558 E-01$ & $1.558 E-01$ & $450 E-01$ & $1.380 E-01$ & $1,298 E=01$ & $1.087 E-01$ & $8.406 E-02$ & $5.716 E-02 \quad 2.890 E-02$ & 0 . \\
\hline 4 & $2.689 E-01$ & $.689 E-01$ & $474 E-01$ & $2.344 E-01$ & $2.199 E-01$ & $1.826 \mathrm{E}-01$ & $1.392 E-01$ & $9.384 E-02 \quad 4.719 E-02$ & 1. \\
\hline 5 & $3.433 E-01$ & $3.433 E-01$ &.$|13 E-0|$ & $2.933 E-01$ & $2.758 E-01$ & $2,290 E-01$ & $1.716 E-01$ & $1.147 E-0 \mid 5.740 E-72$ & 0 \\
\hline 6 & $4.14|E-0|$ & $.|4| E-0 \mid$ & $.741 E-01$ & $3.521 E-01$ & $3.310 E=01$ & $2.745 \mathrm{E}-01$ & $2.047 E-01$ & $1.361 E-01 \quad 0.797 E-02$ & 0 , \\
\hline 7 & $4.818 \mathrm{E}-01$ & $.818 E-01$ & $353 E-01$ & $1.097 E-01$ & $3.852 E-01$ & $3.193 E-01$ & $2.376 E-01$ & $7.858 E-02$ & 0. \\
\hline 8 & $5.466 E-01$ & $5.466 E-01$ & $9.45 E-01$ & $4.658 E-01$ & $4,38|E-0|$ & $3.632 E-01$ & $2.698 E-01$ & $.787 E-01 \quad 8,897 E-02$ & 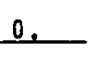 \\
\hline 9 & $6.086 E-01$ & $6.086 E-01$ & $.525 E-01$ & $5.208 E=01$ & $4.899 E-01$ & $4.057 E-01$ & $3,008 E-01$ & $1.988 E-01 \quad 9.889 E-02$ & 0. \\
\hline 10 & $6.672 \mathrm{E}-01$ & $6.672 E-01$ & $.|| 0 E-0 \mid$ & $5.76|E-0|$ & $5.40 \mid E-01$ & $4.46|E-0|$ & $3.298 E-0.1$ & $2.175 E-01 \quad 1.080 E-01$ & 0. \\
\hline 11 & $7.198 E-01$ & $7.198 E-01$ & $6.670 E-01$ & $6.303 E-01$ & $5.874 E-01$ & $4.825 E-01$ & $3.554 E-01$ & $2.339 E-01 \quad 1.160 E-01$ & \\
\hline 12 & $7.618 E-01$ & $7.618 E-01$ & $.083 E-01$ & $6.698 \mathrm{BE}-01$ & $0.239 E-01$ & $5.115 E-01$ & $3.761 E-01$ & $2.472 E-01 \quad 1.225 E-01$ & \\
\hline 13 & $7.914 E-01$ & $.9|4 E-0|$ & $367 E-01$ & $6.969 E-01$ & $0.492 E-01$ & $5.321 E-01$ & $3.910 E-01$ & $2.568 E-01 \quad 1.272 E-01$ & \\
\hline 14 & $8.079 E-01$ & $.079 E-01$ & $.524 E-01$ & $7.119 E-01$ & $0.633 E-01$ & $5.436 E-01$ & $3.994 E-01$ & $2.622 E-01 \quad 1.299 E-01$ & \\
\hline 15 & $8.110 \mathrm{E}-01$ & $8.110 E-01$ & $.555 E-01$ & $7.149 E-01$ & $6.662 E-01$ & $5.46 \mid E-U 1$ & $4.012 E-01$ & $2.634 E-0 i \quad 1.305 E-01$ & 0. \\
\hline 16 & $8.006 E-01$ & $.006 E-01$ & $.460 E-01$ & $7.060 E-01$ & $6.579 E-01$ & $5.395 E-01$ & $3.965 E-01$ & $2.604 E-01 \quad 1.290 E-01$ & 0. \\
\hline 17 & $7.769 E-01$ & $769 E-01$ & $7.241 E-01$ & $6.853 E-01$ & $6.388 E-01$ & $5.240 E-01$ & $3.853 E-01$ & $2.53|E-0| \quad|.254 E-0|$ & 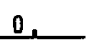 \\
\hline 18 & $7.403 \mathrm{E}-01$ & $.403 E-01$ & $.902 E-01$ & $.534 E-01$ & $0.092 E-01$ & $5.000 E-01$ & $3.679 E-01$ & $2.419 E-01 \quad 1,200 E-01$ & 1 \\
\hline 19 & $6.913 E-01$ & $.913 E-01$ & $.448 E-01$ & $6.106 E-01$ & $5.696 E-01$ & $4.68|E-0|$ & $3.450 E-01$ & $2.27|E-0| \quad|| 28 E-0 \mid$, & \\
\hline 20. & $6.307 E-01$ & $6.307 E-01$ & $.886 E-01$ & $5.578 E-01$ & $5.207 E-01$ & $4.288 E-01$ & $3.171 E-01$ & $1.042 E-01$ & 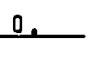 \\
\hline 21 & $5.59|E-0|$ & $5.59|E-0|$ & $224 E-01$ & $4.955 E-01$ & $4.632 E-01$ & $3.831 \mathrm{E}-01$ & $2.855 E-01$ & $1.897 E-01 \quad 9.472 E-02$ & 3 \\
\hline 22 & $4.776 E-01$ & $4.776 E-01$ & $4.470 E-01$ & $4.245 E-01$ & $3.976 E-01$ & $3.3|4 E-0|$ & $2.523 E-01$ & $1.697 E-01 \quad 8.521 E-02$ & 0. \\
\hline 23 & $3.628 E-01$ & $3.628 \mathrm{E}-01$ & $3.405 E-01$ & $3.242 E-01$ & $3.047 E-01$ & $2.568 E-01$ & $1.996 \mathrm{E}-01$ & $1.362 E-01 \quad 6.899 E-02$ & 0. \\
\hline 24 & $3.105 E-01$ & $3.105 E-01$ & $2.920 E-01$ & $2.784 E-01$ & $2.62|E-0|$ & $2.2 \mid 9 E-01$ & $1.735 E-01$ & $1.190 E-01 \quad 6.051 E-02$ & 0 \\
\hline 25 & -0.1 & -01 & $.920 E-01$ & $784 E-01$ & $2.62 \mid E-01$ & $219 E-01$ & $5 E-01$ & $190 E-01 \quad 6.051 E-02$ & \\
\hline
\end{tabular}

Fig. 6 (continued) 
CODE TWENTY GRAND - SAMPLE PROBLEM GROUP ABSORPTIONS

\begin{tabular}{|c|c|c|c|c|c|}
\hline & GROUP-ONE & GR:OUP-TWO & GROUP - THREE & GROUP - F OUR & $\frac{\text { TOTAL }}{19829 F 00}$ \\
\hline \multicolumn{6}{|l|}{ GROUP } \\
\hline & GROUP-ONE & GROUP-TWO & GROUP - THREE & GROUP-FOUR & TOTAL \\
\hline & $5.67242 E-01$ & $2.11147 E-01$ & $1.12267 E-01$ & $1.09344 E-01$ & $10.00000 E-01$ \\
\hline \multicolumn{2}{|c|}{ BOUNDARY LEAKAGES } & TOTAL 2.9 & $4 E \quad 01$ & & \\
\hline & GROUP-ONE & GROUP-TWO & GROUP-THREE & GROUP-FOUF & TOTAL \\
\hline $\begin{array}{l}\text { LFT } \\
\text { TOP }\end{array}$ & $\begin{array}{l}0 . \\
1.29829 E\end{array}$ & $\begin{array}{l}0.76649 E-01 \\
3.7664\end{array}$ & $0.96470 E-01$ & $\begin{array}{l}0.29348 E-01 \\
2.29\end{array}$ & $\begin{array}{ll}0.10070 E & 00 \\
2.1007\end{array}$ \\
\hline $\begin{array}{l}\text { RIT } \\
\text { BOT }\end{array}$ & $\begin{array}{l}1.66651 E 01 \\
0 .\end{array}$ & $\begin{array}{l}5.31529 E \quad 00 \\
0 .\end{array}$ & $\begin{array}{l}2.74834 \mathrm{E} 00 \\
0 .\end{array}$ & $\begin{array}{l}2.91989 E 00 \\
0 .\end{array}$ & $\begin{array}{l}2.76486 E \quad 01 \\
0 .\end{array}$ \\
\hline
\end{tabular}

\section{AXIAL LEAKAGES}

\begin{tabular}{ccccc}
\hline GROUP-ONE & GROUP-TWO & GROUP-THREE & GROUP-FOUR & TOTAL \\
$9.39804 E-01$ & $3.15877 E-01$ & $1.62741 E-01$ & $1.63779 E-01$ & $1.58220 E$ \\
\hline
\end{tabular}

\begin{tabular}{|c|c|c|c|c|c|c|}
\hline REGION & ABSORPTIDNS & & & & & \\
\hline $\begin{array}{c}\text { REG } \\
1\end{array}$ & $\begin{array}{c}\text { GROUP-ONE } \\
1.73908 E-02\end{array}$ & $\begin{array}{c}\text { GROUP-TWO } \\
1.08193 E-02\end{array}$ & $\begin{array}{l}\text { GROUP-THREE } \\
5.82429 E-03\end{array}$ & $\begin{array}{l}\text { GROUP-F OUR } \\
3.41023 E-03\end{array}$ & $\begin{array}{c}\text { TOTAL } \\
3.74447 \mathrm{E}-02\end{array}$ & $\begin{array}{l}\text { REG,VOLUME } \\
1.20000 E \text { O }\end{array}$ \\
\hline $\begin{array}{l}2 \\
3\end{array}$ & $\begin{array}{l}3.64899 E-02 \\
5.65317 E-02\end{array}$ & $\begin{array}{l}1.88231 E-02 \\
7.5740 \mid E-01\end{array}$ & $\begin{array}{l}1.03819 E-02 \\
3.88504 E-01\end{array}$ & $\begin{array}{l}7.82888 E-03 \\
1.26460 E-02\end{array}$ & $\begin{array}{l}7.35238 E-02 \\
1.21508 E 00\end{array}$ & $\begin{array}{l}1.20000 E \text { OI } \\
1.20000 E \text { UI }\end{array}$ \\
\hline $\begin{array}{l}4 \\
5\end{array}$ & $\begin{array}{l}2.45458 E-02 \\
1.94245 F-02\end{array}$ & $\begin{array}{l}5.8544[J E-03 \\
2.67255 E-03\end{array}$ & $\begin{array}{l}3.22564 E-03 \\
1.43583 F-03\end{array}$ & $\begin{array}{l}5.27187 E-03 \\
3\end{array}$ & $\begin{array}{l}3.88977 E-02 \\
2.73269 F-02\end{array}$ & $\begin{array}{l}1.20000 E \\
3.00000 E\end{array}$ \\
\hline $\begin{array}{l}5 \\
7 \\
\end{array}$ & $\begin{array}{l}2.36091 E-01 \\
1.05441 E-01\end{array}$ & $\begin{array}{l}9.04936 E-02 \\
3.51701 E-02\end{array}$ & $\begin{array}{l}4.98474 E-02 \\
1.87707 E-02 \\
\end{array}$ & $\begin{array}{l}5.06833 E-U 2 \\
2.04572 E-0 ?\end{array}$ & $\begin{array}{l}4.27116 E-01 \\
1.79839 E-01 \\
\end{array}$ & $\begin{array}{l}6.00000 E \\
5.40000 E \\
5.41\end{array}$ \\
\hline 8 & $1.11453 E-01$ & $4.23053 E-02$ & $2.29861 F-02$ & $2.23089 E-02$ & $1.99053 E-01$ & $4.100000 E 01$ \\
\hline
\end{tabular}




\begin{tabular}{|c|c|c|c|c|c|c|c|c|}
\hline & & 1 & 2 & 3 & & 4 & & 5 \\
\hline 1 & 0. & 0 . & 0. & 0. & 0 , & 0. & 0. & 0. \\
\hline & 0. & 0 & 0. & 0. & 0. & 0. & 0. & 0. \\
\hline 2 & $\begin{array}{l}0 . \\
0 .\end{array}$ & $\begin{array}{l}0 . \\
0 .\end{array}$ & $\begin{array}{l}-0 \\
-0\end{array}$ & $\begin{array}{l}-0 \\
=0\end{array}$ & $\begin{array}{l}-0 \\
-0,\end{array}$ & $\begin{array}{l}-0 \\
-0 .\end{array}$ & $\begin{array}{l}-0 \\
-0\end{array}$ & $\begin{array}{l}-0 \\
-0\end{array}$ \\
\hline 3 & 0. & 0. & -0. & -0. & -0. & -0. & -0. & -0. \\
\hline & 0. & 0. & -0 . & $=0$. & -0, & -0 & -0. & -0. \\
\hline 4 & 0. & 0. & $\begin{array}{r}-0.919 E-03^{-0} 6.919 E-03 \\
\end{array}$ & $\begin{array}{l}-0.0 \\
0.513 E-03-0.0\end{array}$ & $\begin{array}{l}-0 . \\
-0\end{array}$ & $\begin{array}{l}-0 \\
-0\end{array}$ & $\begin{array}{l}-0 \\
-0\end{array}$ & $\begin{array}{l}-0.1 \\
3.785 E-03\end{array}$ \\
\hline 5 & $\frac{0 .}{0 .}$ & 0. & $\frac{8.693 E-03 \quad 8.693 E-03}{8.693 E-03 \quad 8.693 E-03}$ & $\begin{array}{l}8.099 E-03-0 \\
8.099 E-03-0 .\end{array}$ & $\frac{-0 .}{-0}$ & $\begin{array}{l}-0 . \\
-0 .\end{array}$ & $\frac{-0}{-0 .}$ & $\frac{4.858 E-03}{4.858 E-03}$ \\
\hline 6 & 0. & $\begin{array}{l}0 . \\
0 .\end{array}$ & $\begin{array}{ll}1.032 E-02 & 1.032 E-02 \\
1.032 E-02 & 1.032 E-02 \\
\end{array}$ & $\begin{array}{l}9.588 E-03-0 . \\
9.588 E-03-0 .\end{array}$ & $\begin{array}{l}-0 \\
-0\end{array}$ & $\begin{array}{l}-0 . \\
-0 .\end{array}$ & $\begin{array}{l}-0 \\
-0\end{array}$ & $\begin{array}{l}5.947 E-03 \\
5.947 E-03\end{array}$ \\
\hline 7 & $\frac{0 .}{0 .}$ & $\frac{0}{0 .}$ & 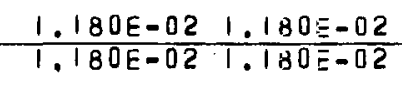 & $\frac{1.095 E-02-0 .}{1.095 E-02-0 .}$ & $\frac{-0}{-0 .}$ & $\frac{-0 .}{-0 .}$ & $\frac{-0}{-0 .}$ & $\frac{7.074 E-03}{7.074 E-03}$ \\
\hline 8 & $\begin{array}{l}0 . \\
0 .\end{array}$ & 0. & \begin{tabular}{l|l|l|l}
$1.311 E-02$ & $1.311 E-02$ \\
$1.311 E-02$ & $1.311 E-02$ \\
\end{tabular} & $\begin{array}{l}1.215 E-02-0 . \\
1.215 E-02-0 .\end{array}$ & $\begin{array}{l}-0 . \\
-0 .\end{array}$ & $\begin{array}{l}-0, \\
-0,\end{array}$ & $\begin{array}{l}-0 \\
-0 \\
\end{array}$ & $\begin{array}{l}8.281 E-03 \\
8.281 E-03 \\
\end{array}$ \\
\hline 9 & 0 & 0. & $\begin{array}{ll}1.425 E-02 & 1.425 E-02 \\
1.425 E-02 & 1.425 E-02\end{array}$ & $\frac{1.317 E-02-0}{1.317 E-02-0 .}$ & & $\begin{array}{l}-0 . \\
-0 .\end{array}$ & $\frac{-0 .}{-0}$ & $\frac{9.661 E-03}{9.661 E-03}$ \\
\hline 10 & $\begin{array}{l}0 . \\
0 .\end{array}$ & $\begin{array}{l}0 . \\
0 .\end{array}$ & $\begin{array}{ll}1.522 E-02 & 1.522 E-02 \\
1.522 E-02 & 1.522 E-02 \\
\end{array}$ & $\begin{array}{l}1.391 E-02=0 \\
1.39 .1 E-02 \quad 1.391 E-02\end{array}$ & $\begin{array}{r}-0 . \\
1.277 E-02 \\
\end{array}$ & $\begin{array}{r}-0 . \\
1.277 E-02 \\
\end{array}$ & $\begin{array}{r}-0.148 E-02 \\
1.148 E\end{array}$ & $\begin{array}{l}1.148 E-02 \\
1.148 E-02 \\
\end{array}$ \\
\hline 11 & $\frac{0 .}{0 .}$ & $\frac{0 .}{0 .}$ & 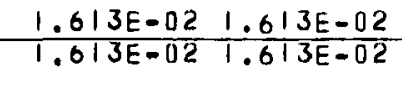 & $\begin{array}{ll}1.484 E-02 & 1.484 E-02 \\
1.484 E-02 & 1.484 E-02\end{array}$ & $\frac{1.389 E-02}{1.389 E-02}$ & $\frac{1.389 E-02}{1.389 E-02}$ & $\frac{1.281 E-02}{1.281 E-02}$ & $\frac{1.281 E-02}{1.281 E-02}$ \\
\hline 12 & $\begin{array}{l}0 . \\
0 .\end{array}$ & $\begin{array}{l}0 . \\
0 .\end{array}$ & $\begin{array}{ll}1.689 \mathrm{E}-02 & 1.689 \mathrm{E}-02 \\
1.689 \mathrm{E}-02 & 1.689 \mathrm{E}-02 \\
\end{array}$ & \begin{tabular}{l|l}
$.564 E-02$ & $1.564 E-02$ \\
$1.564 E-02$ & $1.564 E-02$ \\
\end{tabular} & $\begin{array}{l}1.473 E-02 \\
1.473 E-02 \\
\end{array}$ & $\begin{array}{r}1.473 E-02 \\
1.473 E-02 \\
\end{array}$ & $\begin{array}{l}1.366 E-02 \\
1.366 E-02 \\
\end{array}$ & $\begin{array}{l}1.366 \mathrm{E}-02 \\
1.366 \mathrm{E}-02 \\
\end{array}$ \\
\hline 13 & $\frac{0 .}{0 .}$ & 0. & $\begin{array}{ll}1.745 E-02 & 1.745 E-02 \\
1.745 E-02 & 1.745 E-02\end{array}$ & 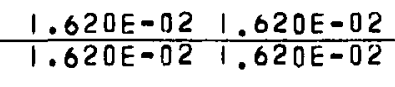 & $\frac{1.530 E-02}{1.530 E-02}$ & $\frac{1.530 E-02}{1.530 E-02}$ & $\frac{1.422 E-02}{1.422 E-02}$ & $\frac{1.422 E-02}{1.422 E-02}$ \\
\hline 14 & $\begin{array}{l}0 . \\
0 .\end{array}$ & $\begin{array}{l}0 . \\
0 .\end{array}$ & $\begin{array}{ll}1.775 E-02 & 1.775 E-02 \\
1.775 E-02 & 1.775 E-02 \\
\end{array}$ & \begin{tabular}{l|l}
$1.65 \mid E-02$ & $.65 \mid E-02$ \\
$1.65 \mid E-02$ & $1.65 \mid E-02$ \\
\end{tabular} & $\begin{array}{l}1.560 E-02 \\
1.560 E-02\end{array}$ & $\begin{array}{l}1.560 E-02 \\
1.560 E-02\end{array}$ & $\begin{array}{l}1.452 E-02 \\
1.452 E-02 \\
\end{array}$ & $\begin{array}{l}1.452 \mathrm{E}-02 \\
1.452 \mathrm{E}-02 \\
\end{array}$ \\
\hline
\end{tabular}

Fig. 6. (continued) 
CODE TWENTY GRAND - SAMPLE PFOBLEM

\section{SOURCE (1, J)}

\begin{tabular}{|c|c|c|c|c|c|c|}
\hline & & 1 & 2 & 3 & 4 & 5 \\
\hline 15 & $\frac{0}{0 .}$ & 0. & 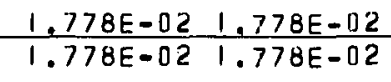 & 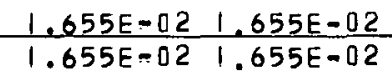 & $\begin{array}{ll}1.565 E-02 & 1.565 E-02 \\
1.565 E-02 & 1.565 E-02\end{array}$ & 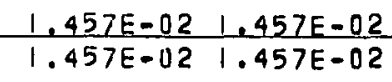 \\
\hline 16 & $\begin{array}{l}0 . \\
0 .\end{array}$ & $\begin{array}{l}0 . \\
0 .\end{array}$ & $\begin{array}{ll}1.752 E-02 & 1.752 E-02 \\
1.752 E-02 & 1.752 E-102 \\
\end{array}$ & $\begin{array}{ll}.632 E-02 & 1.632 E-02 \\
1.632 E-02 & 1.632 E-02 \\
\end{array}$ & $\begin{array}{ll}1.544 E-02 & 1.544 E-02 \\
1.544 E-02 & 1.544 E-02 \\
\end{array}$ & \begin{tabular}{l|l}
$1.43 E E-02$ & $1.438 E-02$ \\
$1.43 E E-02$ & $1.438 E-02$ \\
\end{tabular} \\
\hline 17 & 0. & $\frac{0 .}{0 .}$ & $\begin{array}{ll}1.698 E-02 & 1.698 E-02 \\
1.698 E-02 & 1.698 E-02\end{array}$ & $\frac{1.582 E-02}{1.58 .2 E-02} \frac{1.582 E-02}{1.582 E-02}$ & $\frac{1.497 E-02}{1.4997 E-02}$ & \begin{tabular}{l|l}
$1.395 E-02$ & $1.395 E-02$ \\
$1.395 E-02$ & $1.395 E-02$
\end{tabular} \\
\hline 18 & $\begin{array}{l}0 . \\
0 .\end{array}$ & $\begin{array}{l}0 . \\
0 .\end{array}$ & $\begin{array}{ll}1.616 E-32 & 1 . t \cdot 16 E-02 \\
1.616 E-1] 2 & 1 . t 16 E-02 \\
\end{array}$ & $\begin{array}{ll}1.506 E-02 & 1.506 E-02 \\
1.506 E-02 & 1.506 E-02 \\
\end{array}$ & $\begin{array}{ll}1.425 E-02 & 1.425 E-02 \\
1.425 E-02 & 1.425 E-02 \\
\end{array}$ & $\begin{array}{ll}1.328 E-02 & 1.328 E-02 \\
1.328 E-02 & 1.328 E-02 \\
\end{array}$ \\
\hline 19 & $\frac{0 .}{0 .}$ & 0. & $\begin{array}{ll}1.506 E-02 & 1.506 E-02 \\
1.506 E-02 & 1.506 E-02\end{array}$ & 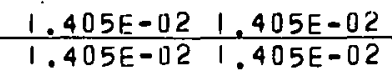 & $\frac{1.330 E-02}{1.330 E-02}$ & $\begin{array}{ll}1.240 E-02 & 1.240 E-02 \\
1.240 E-02 & 1.240 E-02\end{array}$ \\
\hline 20 & $\begin{array}{l}0 . \\
0 .\end{array}$ & 0. & $\begin{array}{ll}.37 \mid E-02 & 1.37 \mid E-02 \\
|.37| E-02 & 1.37 \mid E-02 \\
\end{array}$ & \begin{tabular}{l|l}
$.280 E-02$ & $1.280 E-02$ \\
$1.280 E-02$ & $1.280 E-02$ \\
\end{tabular} & $\begin{array}{ll}1.212 E-C 2 & 1.212 E-02 \\
1.212 E-C 2 & 1.212 E-02 \\
\end{array}$ & $\begin{array}{ll}1.131 E-02 & 1.131 E-02 \\
1.131 E-02 & 1.131 E-02 \\
\end{array}$ \\
\hline 21 & $\frac{0 .}{0 .}$ & $\frac{0 .}{0 .}$ & $\frac{1.212 E-02}{1.21 .212 E-02}$ & 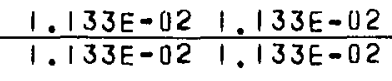 & $\frac{1.074 E-02}{1.074 E-02}$ & $\begin{array}{ll}1.004 E-02 & 1.004 E-02 \\
1.004 E-02 & 1.004 E-02\end{array}$ \\
\hline 22 & $\begin{array}{l}0 . \\
0 .\end{array}$ & 0. & $\begin{array}{r}1.031 E-021.031 E-02 \\
-0.0\end{array}$ & $\begin{aligned} & 9.650 E-03 \\
&-0 . 9.650 E-03 \\
&\end{aligned}$ & $\begin{array}{l}9.163 E-039.163 E-03 \\
-0 . \quad-0 . \\
\end{array}$ & $\begin{aligned} & 8.581 E-03 \\
&-0.58 .1 E-03 \\
&\end{aligned}$ \\
\hline 23 & $\frac{0 .}{0 .}$ & 0. & $\frac{-0}{-0}$ & $\frac{-0}{-0}$ & $\frac{-0 .}{-0 .}$ & $\frac{-0}{-0}$ \\
\hline 24 & $\begin{array}{l}0 . \\
0 .\end{array}$ & $\begin{array}{l}0 . \\
0 .\end{array}$ & $\begin{array}{l}-0 \\
-0 \\
\end{array}$ & $\begin{array}{l}-0 . \\
-0 .\end{array}$ & $\begin{array}{l}-0 . \\
-0 .\end{array}$ & $\begin{array}{l}-0 . \\
-0 .\end{array}$ \\
\hline 25 & $\frac{0 .}{0 .}$ & 0 & 0. & 0. & 0. & 0. \\
\hline
\end{tabular}

Fig. 6 (continued) 


\begin{tabular}{|c|c|c|c|c|c|c|c|c|}
\hline & 6 & 7 & & 8 & & 9 & & \\
\hline 1 & 0. & 0. & 0. & 0. & 0. & 0. & & 0. \\
\hline & 0. & 0. & 0. & 0. & 0. & 0. & 0. & 0. \\
\hline 2 & $\begin{array}{l}-0 \\
-0 \\
\end{array}$ & $\begin{array}{l}-0 \\
-0\end{array}$ & $\begin{array}{l}-0 . \\
-0 .\end{array}$ & $\begin{array}{l}-0 . \\
-0 \\
\end{array}$ & $\begin{array}{l}-0 . \\
-0 .\end{array}$ & $\begin{array}{l}-0 . \\
-0 .\end{array}$ & $\begin{array}{l}0 . \\
0 .\end{array}$ & $\begin{array}{l}0 . \\
0 .\end{array}$ \\
\hline 3 & $\frac{-0}{-0}$ & $\frac{-0}{-0}$ & $\begin{array}{l}-0 . \\
-0 .\end{array}$ & $\frac{-0}{-0}$ & $\frac{-0 .}{-0 .}$ & $\begin{array}{l}-0 . \\
-0 .\end{array}$ & $\frac{0 .}{0 .}$ & 0. \\
\hline 4 & $3.219 E-03^{-0} 3.219 E-03$ & $\begin{array}{r}-0 . \\
2.491 E-03-0 .\end{array}$ & $\begin{array}{l}-0 . \\
-0 .\end{array}$ & $\begin{array}{l}-0 . \\
-0,\end{array}$ & $\begin{array}{l}-0 . \\
-0 .\end{array}$ & $\begin{array}{l}-0 . \\
-0 .\end{array}$ & $\begin{array}{l}0 . \\
0 .\end{array}$ & U. \\
\hline 5 & $\frac{4.136 E-03-4.136 E-03}{4.136 E-034.136 E-03}$ & $\frac{3.144 E-03-0}{3.144 E-03-0}$ & $\frac{-0}{-0}$ & $\frac{-0 .}{-0 .}$ & $\frac{-0}{-0}$ & $\frac{-0}{-0 .}$ & $\frac{0 .}{0 .}$ & 0. \\
\hline 6 & 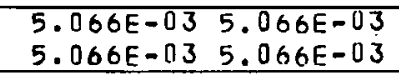 & $\begin{array}{l}3.834 E-03-0 . \\
3.834 E-03-0 .\end{array}$ & $\begin{array}{l}-0 . \\
-0 .\end{array}$ & $\begin{array}{l}-0 . \\
-0 .\end{array}$ & $\begin{array}{l}-0 . \\
-0 .\end{array}$ & $\begin{array}{l}-0 \\
-0 .\end{array}$ & $\begin{array}{l}0 . \\
0 .\end{array}$ & $\begin{array}{l}0 . \\
0 .\end{array}$ \\
\hline 7 & $\frac{6.034 E-03 \quad 6.034 E-03}{6.034 E-036.034 E-03}$ & $\frac{4.557 E-03-0 .}{4.557 E-03-0 .}$ & $\frac{-0}{-0}$ & $\frac{-0}{-0}$ & $\frac{-0}{-0}$ & $\frac{-0}{-0}$ & $\frac{0 .}{0 .}$ & $\frac{0 .}{0 .}$ \\
\hline 8 & $\begin{array}{l}7.063 E-03 \\
7.063 E-03 \\
7.063 E-03 \quad 7.063 E-03 \\
\end{array}$ & $\begin{array}{l}5.317 E-03-0 . \\
5.317 E-03-0 .\end{array}$ & $\begin{array}{l}-0 . \\
-0 .\end{array}$ & $\begin{array}{l}-0 . \\
-0 .\end{array}$ & $\begin{array}{l}-0, \\
-0, \\
\end{array}$ & $\begin{array}{l}-0 . \\
-0 .\end{array}$ & $\begin{array}{l}0 . \\
0 .\end{array}$ & $\begin{array}{l}0 . \\
0 .\end{array}$ \\
\hline 9 & $\frac{8.181 E-03 \quad 8.181 E-03}{8.181 E-03 \quad 8.181 E-03}$ & $\frac{6.110 E-03-0 .}{6.110 E-03-0 .}$ & $\begin{array}{l}-0 . \\
-0 .\end{array}$ & $\frac{-0}{-0}$ & $\frac{-0 .}{-0 .}$ & $\frac{-0 .}{-0 .}$ & 0. & $\frac{0 .}{0 .}$ \\
\hline 10 & 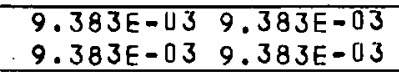 & $\begin{array}{l}0.901 E-03-0 . \\
6.901 E-03-0 .\end{array}$ & $\begin{array}{l}-0 . \\
-0\end{array}$ & $\begin{array}{l}-0 . \\
-0 .\end{array}$ & $\begin{array}{l}-0 . \\
-0 .\end{array}$ & $\begin{array}{l}-0 . \\
-0 .\end{array}$ & 0. & 0. \\
\hline 11 & $\frac{1.038 E-02}{1.038 E-02}$ & $\frac{7.588 E-03-6 .}{7.588 E-03-0 .}$ & $\frac{-0}{-0}$ & $\frac{-0}{-0 .}$ & $\begin{array}{l}-0 . \\
-0 .\end{array}$ & $\begin{array}{l}-0 . \\
=0 .\end{array}$ & $\frac{0}{0}$ & $\frac{0 .}{0 .}$ \\
\hline 12 & $\begin{array}{lll}1.111 E-02 & 1.111 E-02 \\
1.111 E-02 & 1.111 E-02 \\
\end{array}$ & $\begin{array}{l}8.120 E-03-0 . \\
8.120 E-03-0 .\end{array}$ & $\begin{array}{l}-0 \\
-0\end{array}$ & $\begin{array}{l}-0 . \\
-0 .\end{array}$ & $\begin{array}{l}-0 . \\
-0,\end{array}$ & $\begin{array}{l}-0 . \\
-0 .\end{array}$ & $\begin{array}{l}0 . \\
0 .\end{array}$ & $\begin{array}{l}0 . \\
0 .\end{array}$ \\
\hline 13 & 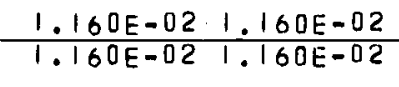 & $\frac{8.485 E-03-0 .}{8.485 E-03-0 .}$ & $\frac{-0}{-0}$ & $\frac{-0}{-0}$ & $\frac{-0}{-0}$ & $\frac{-0}{-0}$ & $\frac{0 .}{0 .}$ & $\frac{0 .}{0 .}$ \\
\hline 14 & \begin{tabular}{l|l}
$1.187 E-02$ & $1.187 E-02$ \\
$1.187 E-02$ & $1.187 E-02$ \\
\end{tabular} & $\begin{array}{l}8.689 E-03-0 . \\
8.689 E-03-0 .\end{array}$ & $\begin{array}{l}-0 \\
-0 \\
-0\end{array}$ & $\begin{array}{l}-0 \\
-0\end{array}$ & $\begin{array}{l}-0 . \\
-0 .\end{array}$ & $\begin{array}{l}-0 . \\
-0 .\end{array}$ & $\begin{array}{l}0 . \\
0 .\end{array}$ & 0. \\
\hline
\end{tabular}

Fig. 6 (continued) 
CODE TWENTY GRAND - SAMPLE PROBLEM

SOURCE (1,N)

7

8

9

10

$\begin{array}{rlll}15 \quad 1.192 E-02 & 1.192 E-02 & 8.736 E-03-0 .\end{array}$ $\begin{array}{ll}-0 & -0 \\ -0 & -0\end{array}$ $-0$. $\frac{-0 .}{-0}$ 0.

\begin{tabular}{|c|c|c|c|c|c|c|c|c|}
\hline 16 & $\begin{array}{ll}1.177 E-02 & 1.177 E-02 \\
1.177 E-02 & 1.177 E-02 \\
\end{array}$ & $\begin{array}{l}8.632 E-03-0 . \\
8.632 E-03-0 .\end{array}$ & $\begin{array}{l}-0 \\
-0\end{array}$ & $\begin{array}{l}-0 \\
-0 \\
\end{array}$ & $\begin{array}{l}-0 . \\
-0 .\end{array}$ & $\begin{array}{l}-0 \\
-0 \\
\end{array}$ & $\begin{array}{l}0 . \\
0 .\end{array}$ & $\begin{array}{l}0 . \\
0 .\end{array}$ \\
\hline 17 & $\frac{1.143 E-02}{1.1443 E-02}$ & $\frac{8.334 E-03-0}{8.334 E-03-0}$ & $\frac{-0}{-0}$ & $\frac{-0 .}{-0 .}$ & $\frac{-0 .}{-0 .}$ & $\frac{-0 .}{-0 .}$ & $\frac{0 .}{0 .}$ & $\frac{0 .}{0 .}$ \\
\hline 18 & $\begin{array}{ll}1.089 E-02 & 1.089 E-02 \\
1.089 E-02 & 1.089 E-02 \\
\end{array}$ & $\begin{array}{l}7.999 E-03-0 . \\
7.999 E-03-0 .\end{array}$ & $\begin{array}{l}-0 . \\
=0 .\end{array}$ & $\begin{array}{l}-0 . \\
-0 .\end{array}$ & $\begin{array}{l}-0 . \\
-0 \text {. }\end{array}$ & $\begin{array}{l}-1 . \\
-0 .\end{array}$ & $\begin{array}{l}0 . \\
0 .\end{array}$ & 0. \\
\hline 19 & $\frac{1.018 E-02 \quad 1.018 E-02}{1.018 E-021.018 E-02}$ & $\frac{7.490 E-03-0 .}{7.490 E-03-0 .}$ & -0 & $\frac{-0}{-0}$ & $\frac{-0}{-0}$ & $\frac{-0 .}{-0 .}$ & 0. & $\frac{0 .}{0 .}$ \\
\hline 20 & 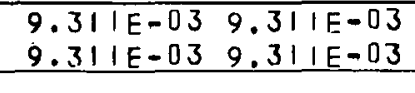 & $\begin{array}{l}6.873 E-03-0 . \\
6.873 E-03-0 .\end{array}$ & $\begin{array}{l}-0 \\
-0\end{array}$ & $\begin{array}{l}-0 \\
-0\end{array}$ & $\begin{array}{l}-0 . \\
-0 .\end{array}$ & $\begin{array}{l}-0 \\
-0 \\
\end{array}$ & $\begin{array}{l}0 . \\
0 .\end{array}$ & 0. \\
\hline 21 & $\frac{8.296 E-43 \quad 8.296 E-03}{8.296 E-038.296 E-03}$ & $\frac{6.173 E-03-0 .}{6.173 E-03-0 .}$ & $\frac{-0}{-0}$ & $\begin{array}{l}-0 \\
-0\end{array}$ & $\frac{-0}{-0}$ & $\frac{-0 .}{-0 .}$ & 0. & $\frac{0 .}{0 .}$ \\
\hline 22 & $\begin{aligned} & 7.147 E-03 \\
&-0.147 E-03 \\
&-0.1\end{aligned}$ & $\begin{array}{r}5.436 \mathrm{E}-03-0 . \\
-0 . \\
-0 .\end{array}$ & $\begin{array}{l}-0 \\
-0\end{array}$ & $\begin{array}{l}-0 \\
-0\end{array}$ & $\begin{array}{l}-0 \\
-0\end{array}$ & $\begin{array}{l}-0 . \\
-0 . \\
\end{array}$ & $\begin{array}{l}0 . \\
0 .\end{array}$ & $\begin{array}{l}0 . \\
0 .\end{array}$ \\
\hline 24 & $\begin{array}{l}-0 \\
-0 \\
\end{array}$ & $\begin{array}{l}-0 \\
-0\end{array}$ & $\begin{array}{l}-0 . \\
-0 . \\
\end{array}$ & $\begin{array}{l}-0 \\
-0\end{array}$ & $\begin{array}{l}-0 \\
-0 \\
\end{array}$ & $\begin{array}{l}-0 \\
-0\end{array}$ & 0. & $\begin{array}{l}0 . \\
0 .\end{array}$ \\
\hline 25 & $\frac{0 .}{0}$ & $\frac{0 .}{0 .}$ & 0. & 0. & $\frac{0 .}{0 .}$ & 0. & $\frac{0 .}{0 .}$ & $\frac{0 .}{0 .}$ \\
\hline
\end{tabular}

Fig. 6 (continued) 
CODE TWENTY GRAND - SAMPLE PROBLEM

\begin{tabular}{|c|c|c|c|c|c|}
\hline \multicolumn{6}{|c|}{ ADJOINT FLUX CALCULATION BEGINS } \\
\hline $\begin{array}{c}I T \\
10\end{array}$ & $\begin{array}{l}\text { FLUX CONVR } \\
1.4093 E-01\end{array}$ & $\begin{array}{c}\text { NU-CRIT CONVR } \\
0 .\end{array}$ & $\begin{array}{l}\text { TOT RESIDUE } \\
1.8226 E 00\end{array}$ & $\begin{array}{l}\text { MAX RES I DUE } \\
1.6782 E-01\end{array}$ & $\begin{array}{l}\text { NUACRITICAL } \\
1.00000 E \text { OD }\end{array}$ \\
\hline $\begin{array}{l}20 \\
30 \\
\end{array}$ & $\begin{array}{l}3.9511 E-02 \\
5.5441 E-03\end{array}$ & $\begin{array}{l}0 . \\
0 .\end{array}$ & $\begin{array}{l}2.7536 E-01 \\
2.9506 E-92\end{array}$ & $\begin{array}{l}3.5659 E-02 \\
3.3140 E-03\end{array}$ & $\begin{array}{lll}1.00000 E & 00 \\
1.00000 E & 00\end{array}$ \\
\hline $\begin{array}{l}40 \\
50\end{array}$ & $\begin{array}{l}6.6382 E-04 \\
1.0085 E-04\end{array}$ & $\begin{array}{l}0 . \\
0 .\end{array}$ & $\begin{array}{l}3.5094 E-03 \\
6.5316 E-04\end{array}$ & $\begin{array}{l}6.2329 E-04 \\
1.1430 E-04\end{array}$ & $\begin{array}{l}1.0 .0000 E 00 \\
1.00000 E 00\end{array}$ \\
\hline $\begin{array}{l}60 \\
70\end{array}$ & $\begin{array}{l}1.9238 E-05 \\
3.9488 E-06\end{array}$ & 0. & $\begin{array}{l}1.4470 E-04 \\
4.0099 E-05\end{array}$ & $\begin{array}{l}2.2833 E-05 \\
5.1118 E-06\end{array}$ & $\begin{array}{l}1.00000 E 00 \\
1.00000 E 00\end{array}$ \\
\hline
\end{tabular}

Fig. 6 (continued) 
CODE TWENTY GRAND - SAMPLE PROBLEM

NO.1T.\#70 NU-CRII\# 1.00000E OO

N.F.C(IOI PROD)\# $5.71794 E-01$

GROUP I ADJOINT FLUX

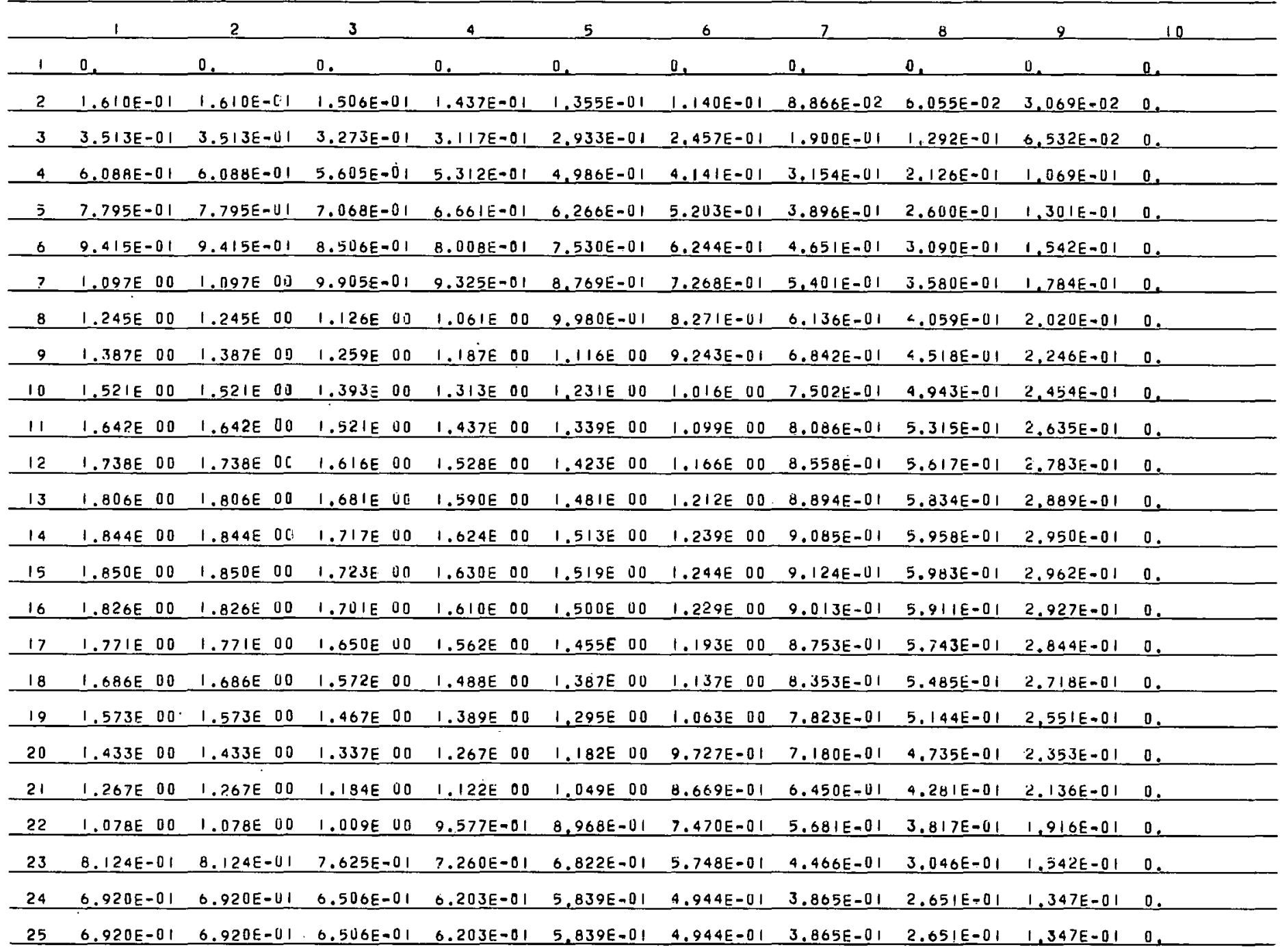

Fig. 6 (continued) 
CODE TWENTY GRAND - SAMPLE PROBLEM

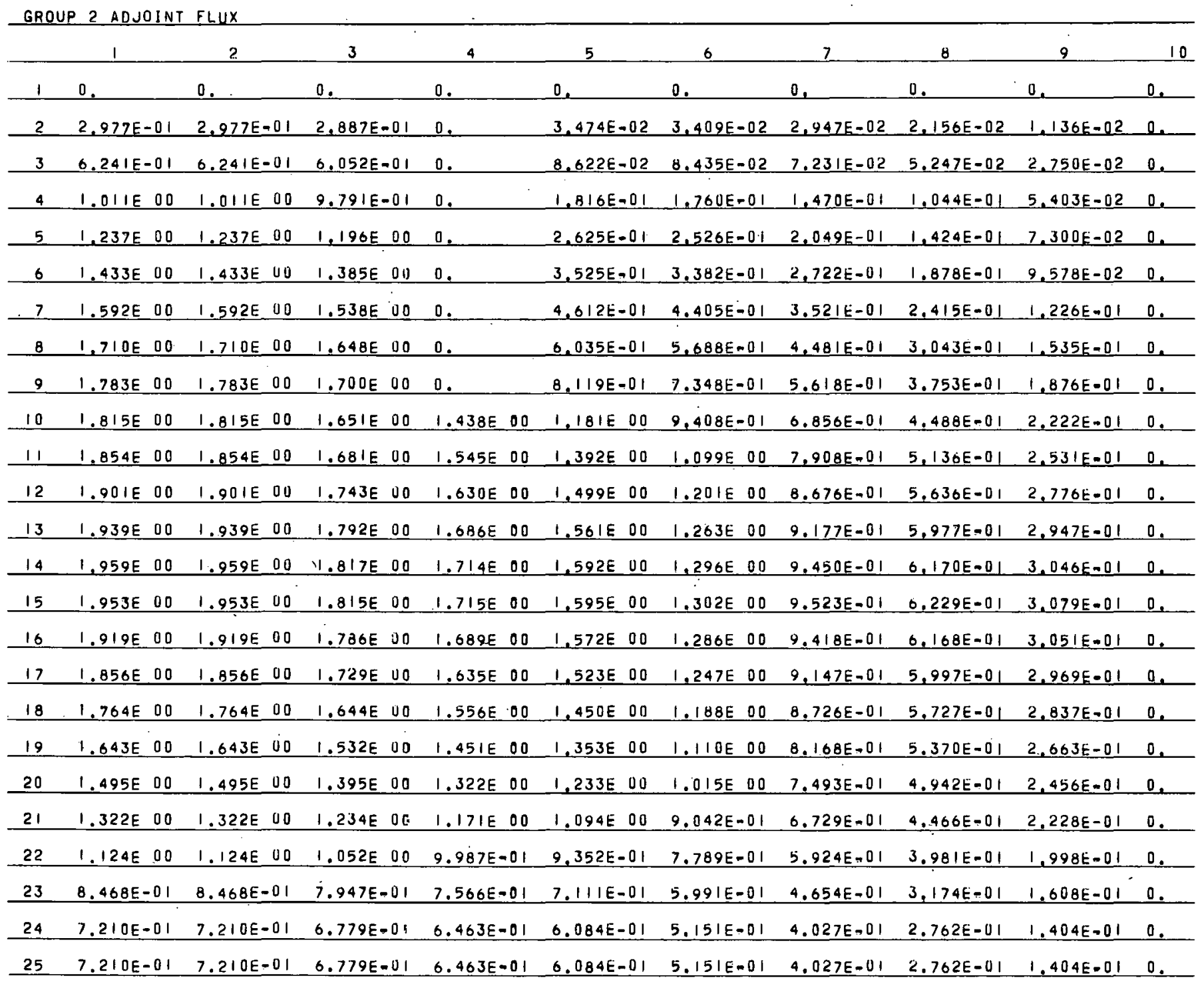

Fig. 6 (continued) 
CODE TWENTY GRAND - SAMPLE PROBLEM

GROUP 3 ADJOINT FLUX

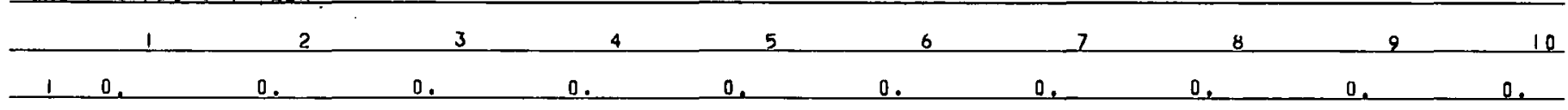

$23.079 E-01 \quad 3.079 \equiv-01 \quad 2.987 E-01 \quad 0$, $3.622 E-02 \quad 3.554 E-02 \quad 3.071 E-02 \quad 2.246 E-02 \quad 1.184 E-02 \quad 0$.

$36.456 E-111 \quad 6.456 E-01 \quad 6.263 E-01 \quad 0$. $\begin{array}{llllll}8.978 E-02 & 8.780 E-02 & 7.525 E-02 & 5.459 E-02 & 2.860 E-02 & 0 .\end{array}$

$4 \quad 1.046 E \quad 00 \quad 1.046 E \quad 00 \quad 1.014 E 00 \quad 0$. $\begin{array}{lllllll}1.887 E-01 & 1.829 E-01 & 1.528 E-01 & 1.085 E-01 & 5.612 E-02 & 0 .\end{array}$

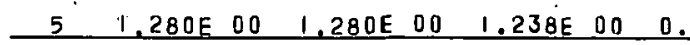
$\begin{array}{llllll}2.725 E-01 & 2.622 E-01 & 2.127 E-01 & 1.478 E-01 \quad 2.577 E-02 & 0 .\end{array}$

$\begin{array}{llllllll}6 & 1.483 E \quad 00 & 1.483 E & 00 & 1.434 E & 00 & 0 .\end{array}$ $3.658 E-01 \quad 3.509 E-01 \quad 2.824 E-01 \quad 1,948 E-01 \quad 9.935 E-02 \quad 0$.

$\begin{array}{llllllll}7 & 1.648 E & 00 & 1.648 E & 00 & 1.593 E & 00 & 0 .\end{array}$ $\begin{array}{lllllll}4.784 E-01 & 4.568 E-01 & 3.650 E-01 & 2.504 E-01 & 1.271 E-01 & 0 .\end{array}$

$\begin{array}{lllllllll}8 & 1.770 E & 00 & 1.770 E & 00 & 1.706 E & 00 & 0 .\end{array}$ $6.256 E-01 \quad 5.895 E-01 \quad 4.644 E-01 \quad 3,154 E-01 \quad 1,590 E-01 \quad 0$.

$\begin{array}{lllllll}9 & 1.845 E \quad 00 & 1.845 E & 00 & 1.760 \equiv 00 & 0 .\end{array}$ $8.411 E-01 \quad 7.611 E-01 \quad 5.820 E-01 \quad 3.887 E-01 \quad 1.943 E-01 \quad 0$. $\begin{array}{lllllllllllllllll}10 & 1.878 E & 00 & 1.878 E & 00 & 1.709 E & 00 & 1.488 E & 00 & 1.222 E & 00 & 9.741 E-01 & 7.099 E-01 & 4.646 E-01 & 2.300 E-01 & 0 .\end{array}$

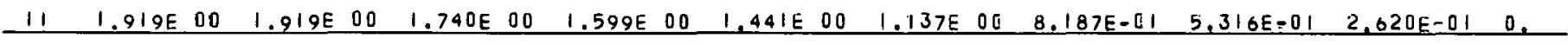
$\begin{array}{lllllllllllllllll}12 & 1.967 E & 00 & 1.967 E & 00 & 1.804 E & 00 & 1.686 E & 00 & 1.551 E & 00 & 1.243 E & 00 & 8.979 E-01 & 5.832 E-01 & 2.873 E-01 & 0 .\end{array}$ $\begin{array}{lllllllllllllllll}13 & 2.006 E & 0 & 2.006 E & 00 & 1.854 E & 00 & 1.744 E & 00 & 1.615 E & 00 & 1.307 E & 00 & 9.496 E-01 & 0.184 E-01 & 3.049 E-01 & 0.0\end{array}$

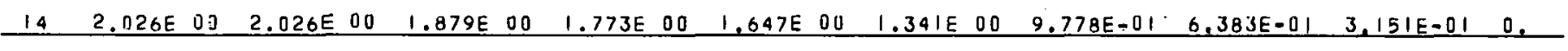
$\begin{array}{lllllllllllllllllll}15 & 2.020 E & 00 & 2.020 E & 00 & 1.878 E & 00 & 1.774 E & 00 & 1.650 E & 00 & 1.347 E & 00 & 9.853 E-01 & 0.444 E-01 & 3.185 E-01 & 0 .\end{array}$ $\begin{array}{llllllllllllllllll}16 & 1.985 E & 00 & 1.985 E & 00 & 1.847 E & 00 & 1.747 E & 00 & 1.026 E & 00 & 1.330 E & 00 & 9.743 E-01 & 0.380 E-01 & 3.156 E-01 & 0 .\end{array}$ $17 \quad 1.920 E 00 \quad 1.920 E \quad 00 \quad 1.788 E \quad 00 \quad 1.691 E \quad 00 \quad 1.576 E \quad 00 \quad 1.290 E \quad 00 \quad 9.462 E-01 \quad 0.203 E-01 \quad 3,070 E-01 \quad 0$ E $\begin{array}{lllllllllllllllll}18 & 1.825 E & 00 & 1.825 E & 00 & 1.700 E & 00 & 1.609 E & 00 & 1.499 E & 00 & 1.229 E & 00 & 9.026 E-01 & 5.923 E-01 & 2.934 E-01 & 0 .\end{array}$ $\begin{array}{lllllllllllllllll}19 & 1.699 E & 00 & 1.699 E & 00 & 1.584 E & 00 & 1.500 E & 00 & 1.399 E & 00 & 1.148 E & 00 & 8.448 E-01 & 5.553 E-01 & 2.754 E-01 & 0 .\end{array}$ $20 \quad 1.546 E \quad 00 \quad 1.546 E \quad 00 \quad 1.443 E \quad 00 \quad 1.367 E 00 \quad 1.275 E \quad 00 \quad 1.050 E \quad 00 \quad 7.749 E-01 \quad 5.109 E-01 \quad 2.539 E-01 \quad 0.2$

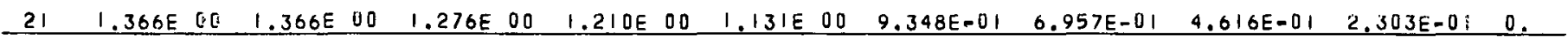
$22 \quad 1.162 E \quad 00 \quad 1.162 E \quad 00 \quad 1.087 E \quad 00 \quad 1.032 E \quad 00 \quad 9.065 E-01 \quad 8.051 E-01 \quad 0.123 E-01 \quad 4.114 E-01 \quad 2.065 E-01 \quad 0$. $23 \quad 8.745 E-01 \quad 8.745 E-01 \quad 8.207 E-01 \quad 7.814 E-01 \quad 7.344 E-01 \quad 0.187 E-01 \quad 4.807 E-01 \quad 3.278 E-01 \quad 1.660 E-01 \quad 0.01$ $24 \quad 7.443 E-01 \quad 7.443 E-01 \quad 6.997 E-01 \quad 6.671 E-01 \quad 6.280 E-01 \quad 5.317 E-01 \quad 4.157 E-01 \quad 2.851 E-01 \quad 1.449 E-01 \quad 0.01$ $25 \quad 7.443 E-01 \quad 7.443 E-01 \quad 6.997 E-01 \quad 6.671 E-01 \quad 6.280 E-01 \quad 5.317 E-01 \quad 4.157 E-01 \quad 2.851 E-01 \quad 1.449 E-01 \quad 0$.

Fig. 6 (continued) 


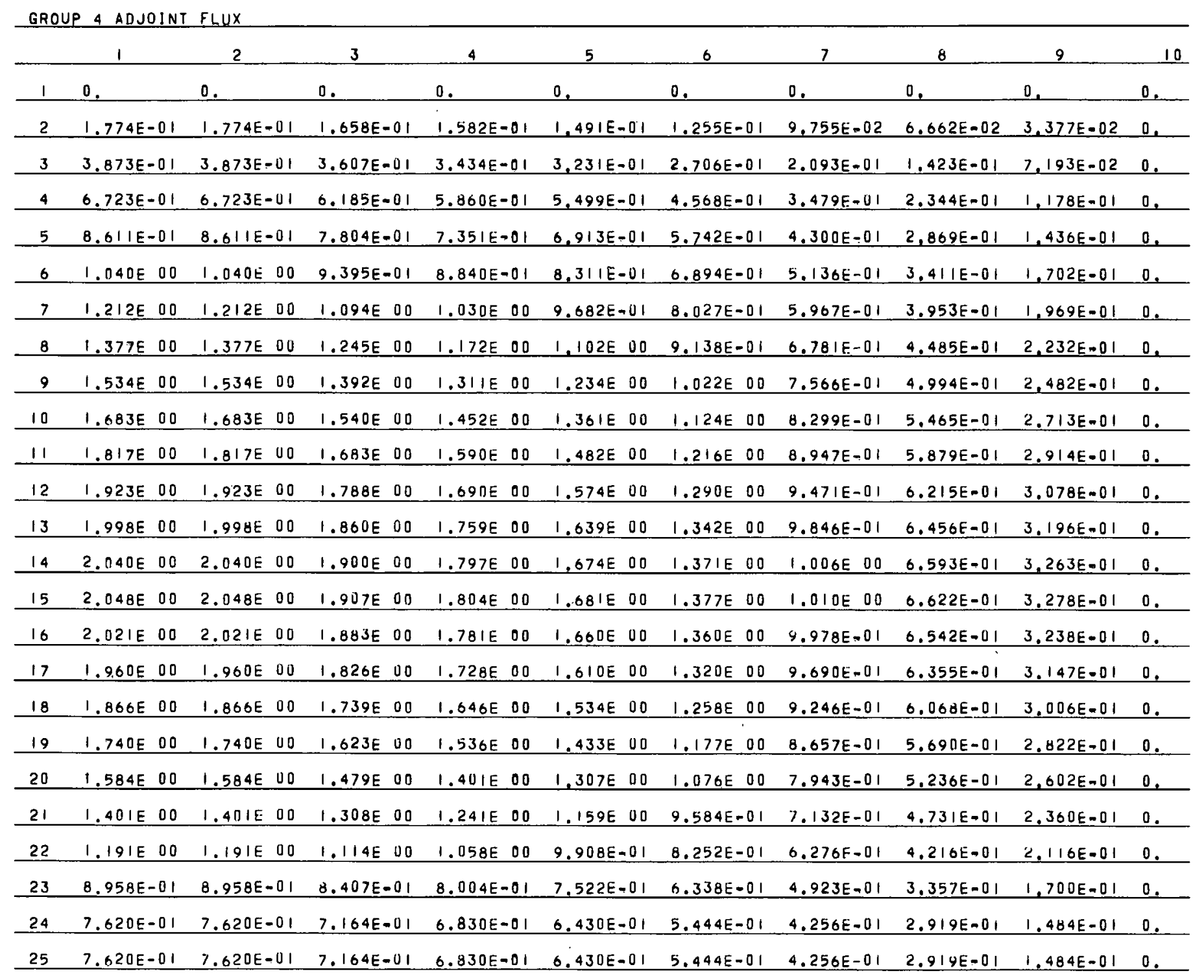

Fig. 6 (continued) 
CODE TWENTY GRAND - SAMPLE PROBLEM

\section{(FLUXIY(ADUOINT-FLUX) REGION INTEGFALS}

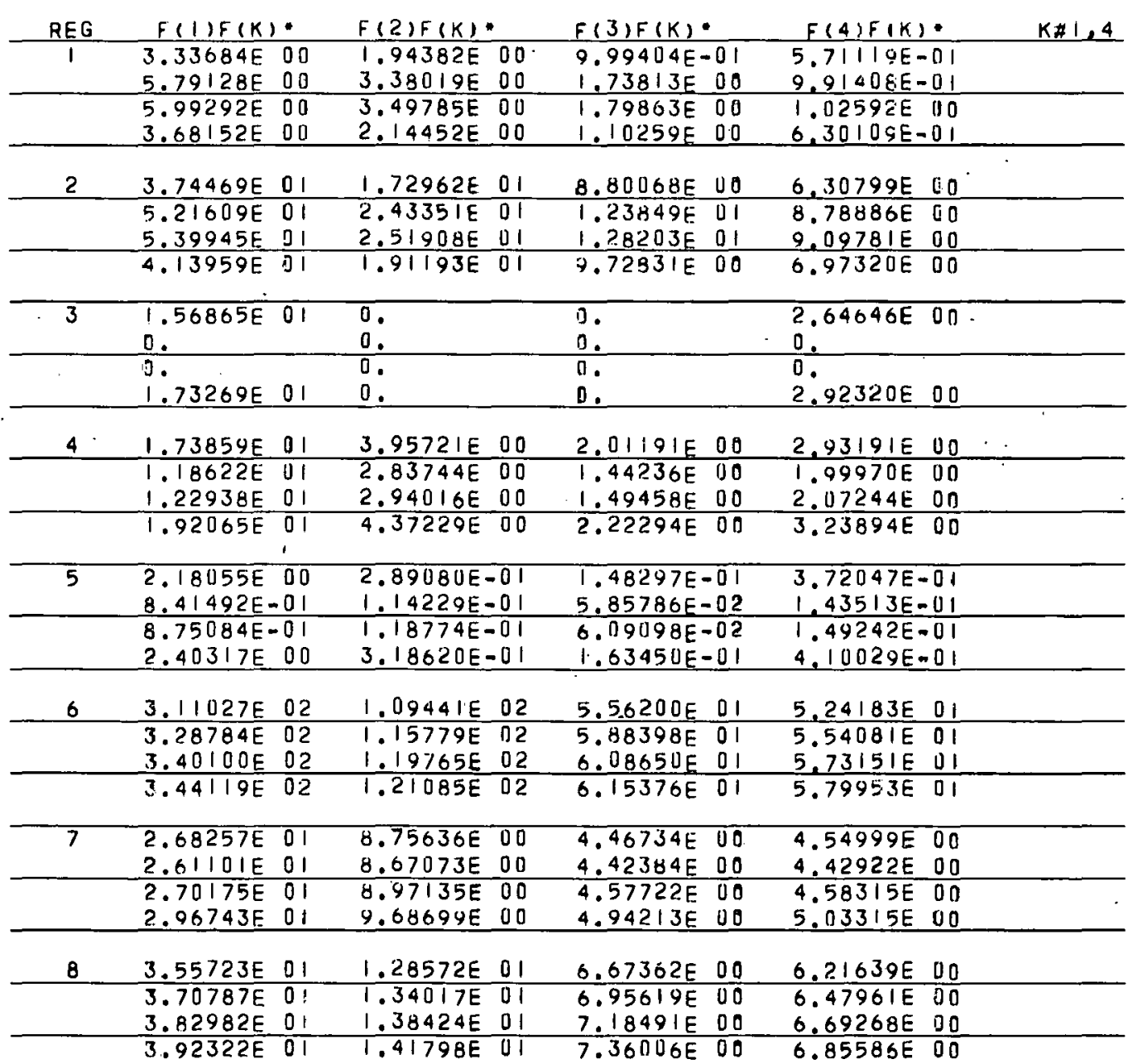

Fig. 6 (continued) 
CODE TWENTY GRAND - SAMPLE PROBLEM

(DEL-FLUX). (ADJOINT DEL-FLUX) REGION INTEGRALS

\begin{tabular}{|c|c|c|c|c|}
\hline REG & $D F(1) D F(1)$ & $D F(2) D F(2)$. & $D F(3) D F(3)$ & $D F(4) D F(4)$. \\
\hline 1 & $\begin{array}{l}3.29840 E-01 \\
8.70550 E-01\end{array}$ & $\begin{array}{l}2.95591 E-01 \\
2.54768 E-01\end{array}$ & $\begin{array}{l}1.56692 E-01 \\
1.32525 E-01\end{array}$ & $\begin{array}{l}6.19644 E-12 \\
1.60746 E-01\end{array}$ \\
\hline $\begin{array}{l}3 \\
4\end{array}$ & $\begin{array}{l}6.21464 E-01 \\
1.26783 E 00\end{array}$ & $\begin{array}{l}0.25857 E-01 \\
3.258\end{array}$ & $0.70887 E-01$ & $\begin{array}{l}1.15769 E-01 \\
2.34595 E-01\end{array}$ \\
\hline 5 & $4.39605 E-01$ & $2.52982 E-02$ & $1.34438 E-02$ & $8.25224 E-02$ \\
\hline 6 & $7.37338 E \quad 00$ & $2.91184 E \quad 00$ & $1.52151 E 00$ & $1.36026 E \quad 00$ \\
\hline $\begin{array}{l}7 \\
8\end{array}$ & 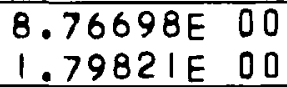 & $\begin{array}{l}2.86636 E=00 \\
6.66097 E-01\end{array}$ & $\begin{array}{l}1.51127 E=00 \\
3.54090 E=01\end{array}$ & $\begin{array}{l}1.64213 E=00 \\
3.41771 E-01\end{array}$ \\
\hline
\end{tabular}

Fig. 6 (continued) 


\section{Internal Distribution}

1. L. G. Alexander

2. V. E. Anderson $(\mathrm{K}-25)$

3. S. E. Beall

4. M. Bender

5. L. I. Bennett

6. A. L. Boch

7. W. L. Breazeale

8. R. B. Briggs

9. R. S. Carlsmith

10. W. L. Carter

11. R. D. Cheverton

12. H. C. Claiborme

13. A. L. Colomb

14. R. R. Coveyou

15. J. G. Delene

16. A. C. Downing

17-21. T. B. Fowler

22. A. P. Fraas

23. E. H. Gift

24. D. R. Gilfillan

25. E. E. Gross

26. A. S. Householder

27. W. H. Jordan

28. P. R. Kasten

29. W. E. Kinney

30. .T. A. Lane

31. C. E. Larson (K.-25)

32. M. P. Tietzke

33. R. N. Lyon

34. H. G. Mac.Pherson

35. W. D. Manly

36. B. Maskowitz (K-25)

37. A. J. Miller
38. E. A. Nephew

39. C. W: Nestor, Jr.

40. C. E. Newlon $(\mathrm{K}-25)$

41. A. M. Perry

42. P. H. Pitkanen

43. C. A. Preskitt

44. B. E. Prince

45. M. W. Rosenthal

46. T. H. ROW

47. J. E. Rowe $(\mathrm{K}-25)$

48. H. W. Savage

49. A. W. Savolainen

50. E. G. Silver

51. M. J. Skinner

52. I. Spiewak

53. J. G. Sullivan

54. J. A. Swartout

55-59. M. L. Tobias

60. D. B. Trauger

61. M. E. Tsagaris

62. R. Van Winkle

63. D. R. Vondy

64. D. W. Vroom

65. A. M. Weinberg

66. F. G. Welfare $(Y-12)$

67. C. E. Winters

68-90. Laboratory Records Department

91. Laboratory Records, LRD-RC

92-93. Central Research Library

94-96. Y-12 Technical Library, Document Reference Section

97-98. Reactor Division Library

99. SHARE Lj.brary $(K-25)$

\section{External Distribution}

100. C. P. Bhalla, Westinghouse Electric Corporation, Atomic Power Department, Pittsburgh, Pa.

101. L. R. Blue, Atomics International, Canoga Park, Calif.

102. W. Cartwell, System Analysis and Computation, IBM, Owego, New York 
103. R. I. Crowther, Atomic Power Department, General Electric Co., San Jose, Calif.

104. E. M. Gelbard, Westinghouse Electric Corporation, Bettis Plant, Pittsburgh, Pa.

105. D. H. Groelsema, AEC, Washington

106. Haig Iskenderian, Argonne National Laboratory

107. D. Jacobson, Argonne National Laboratory

108. Seymour Jaye, General Atomic, San Diego, Calif.

109. W. B. Lee, Lockheed Nuclear Products, Atlanta, Georgia

110. D. J. Mallon, Allison Division, General Motors Corp., Indianapolis, Indiana

111. T. F. McKiernan, Pratt \& Whitney Aircraft, Hartford, Conn.

112. B. H. Mount, Westinghouse Electric Corp. Bettis Plant, Pittsburgh, $\mathrm{Pa}$.

113. W. Sangren, General Atomic, San Diego, Calif.

114. D. M. Shapiro, Intermuclear Company, Clayton, Missouri

115. D. W. Thomas, Aerojet-General Nucleonics, San Ramon, Calif.

116. Division of Research and Development, $\mathrm{AEC}$, ORO

117-118. Reactor Division, AEC, ORO

119-726. Given distribution as shown in TID-4500 (16th ed.) under

Mathematics and Computers category ( 75 copies - OTS) 